\title{
エナメル上皮腫に侵された下顎弓形態 の再建に関する臨床的研究
}

\author{
九州歯科大学第 2 口腔外科学教室 (指導 : 池尻 茂前教授) \\ (指導：梶山 稔教授) \\ 今 里 照 夫
}

昭和53年 1 月19日受付

(本論文の要旨は昭和 46 年 4 月 4 日第25回日本口腔科学会総会および昭和52年12月 26 日九州䨑科学会12月例 会において発表した.)

Clinical Study on Reconstruction in the Form of Mandibular Arch Affected with Ameloblastoma

\section{By}

Teruo Imazato

\begin{abstract}
Second Department of Oral Surgery (Director : former Prof. Shigeru Ikejiri)
(Director : Prof. Minoru Kajiyama)

Kyushu Dental College, Kitakyushu, Japan
\end{abstract}

Ameloblastoma is classified pathologically into benign tumors, and of the tumors occurring in the jaw, more than 80 per cent occur in the mandible as opposed to the maxilla. Clinically, however, the ameloblastoma is a slow growing malignant tumor. On this view point, the most effective treatment of ameloblstoma with associated extension can only be accomplished by en bloc resection of the affected segment of mandible. The other conservative treatments (cautery, curettage, excision and partial or segmental resection) often fail to cure the patients. Shatkin (1965), Mehlish (1972) and many other researchers report the frequent recurrence of this tumor and several cases of tumor death as a result of inadequate treatments.

Despite of such caution, Stout (1963) and some other authors favor and substantiate a conservative surgical approach as an initial treatment of choice for ameloblastoma. The reason for this contention is the fear of damaging continuity of mandibular arch by en bloc resection. So far, numerous methods of reconstructive surgery for mandibular defect following arch resection have been undertaken and published. In our Second Department of Oral Surgery, almost all of ameloblastomas have been treated by en bloc resection and simutaneous reconstruction with autogenous bone graft, excepting case of peripheral tumors. The resulting condition is exactly a serious problem for the patient and surgeon from aesthetc, psychological, and functional standpoint. Neverthe- 
less, no literature has yet been contained and subtilized a theme of postoperative condition following mandible resection with simultaneous reconstruction, but our previous seriese of reports. Accordingly, I investigated the postoperative features of mandibular arch in 35 patients of ameloblastoma operated with en bloc resection and simult aneous reconstruction.

These patients' age at the operation were distributed from 9 to 76 years old. And the patinets were seen 1 year to 13 years and 11 months after the operation. The results obtained were summarized as follows.

1. Twenty cases of 35 patients were evaluated as a group of good feature associating no deformity during rest and function. The other 15 cases were pointed out as having slight deformities. The contents of these deformities were flat cheek (in 11 cases), mandibular deviation (in 8 cases), linear angle (in 4 cases), mandibular shortening (in 3 cases), and submandibular hollow (in 2 cases). No severe deformity was observed in these seriese.

2. All cases operated on the anterior part of mandible were evaluated as having good features. Secondly, those operated on mandibular body, especially those reconstructed with iliac bone graft, were evaluated as better. Therefore, the bent rib graft and/or the cortex replantation is useful for reconstruction of the antrior part of mandible. Then, the iliac bone graft will be initial indication for the reconstruction of mandibular body rather than the cortex replantation.

3. The group operated on the posterior part of mandible revealed some deformities in almost all cases. As special features of these deformities, almost all cases operated on angular part were caracteristics of flat cheek and linear angle, and the cases operated with hemimandibuloectomy including the condyle were caracteristics of deviation and flat cheek. It was suggested that cortex replantation is slightly superior to iliac bone graft as a reconstructive procedure for these posterior region of mandible.

4. Orthopantomograms have a bright future as a means of examining mandibular contour for expectation of considerable standardization, laying aside the characteristic of biased figure. As a result of analysis of orthopantomograms of 25 patients among the subjects, mandibular shortening of reconstructed area and flattening of angle were indicated.

5. In a long-period follow up of 8 cases postoperatively, the possibility of deformation of reconstructed mandible existed during the first 8 months. On the other hand, the condition 1 year postoperatively was stable.

6. Regeneration and new growth of bone was found in 6 cases operated at the ages of $9,18,23,37$ and 44 . In one of 9-year-old, nearly perfect regeneration of condyle and coronoid process which can hardly be distinguished from the normal (non-operated) side was observed. And another 23-year-old revealed the regeneration of spina mentalis on the grafted bent rib.

On the basis of above results, the simultaneous reconstruction of mandible with aut- 
ogenous bone graft should be the treatment of choice for repair with good feature of mandible, provided that an adequate fixation and stabilization within 1 year of postoperative period will be applied for further improvement of operation result.

\section{緒 言}

エナメル上皮腫に対する治療は種々の方法が行われて いる.すなわち焼灼,掻爬，腫瘍剔出あるいは部分切除， さらに顥骨離断等である.

前 3 者の方法は及ぼす侵襲が小さいために時に好んで

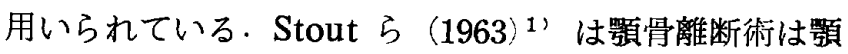
の連続性を損うとして, 腫瘍の大きさに関係なく，出来 る限り姑息的 (conservative surgical approach) に 治療するよう勧めている。しかしながら，てのような治 療法には再発例がしばしばみられ，腫煌死例の報告もな されている2,31.

そこで Mehlish ら $(1972)^{2)}$ は腫場径が $5 \mathrm{~cm}$ 以上 の場合は類骨離断による広範切除を行うべきだと主張 し, Shatkin ら (1965) ${ }^{31}$ はエナメル上皮腫を悪性腫痬 と見做して徹底的根治手術を行うべきだと述へている。

教室では，エナメル上皮腫の浸洞性発育 ${ }^{4}$ という特性 を重視して, 出来る限り広範に切除して再発を防止する 方針を採用している．すなわち Mehlish ら $(1972)^{22}$ が主張しているように，腫場が小さく辺縁性に限局して いる場合にのみ腫瑒切除を行い，その他の症例では健康 部を含めた広範切除（多くの場合，頻骨連続離断）を適 用し，全例に扔いて未だ再発例は見ていない。

このように，䫓骨離断を含む広範切除がエナメル上皮 腫に対して優れた処置であるのは明らかである：にも拘 わらず，上り治療成績の劣る姑息的治療法が好まれるの

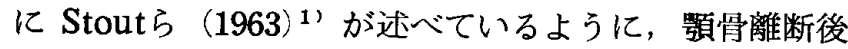
の変形への懸念が強いためと思われる，著者等の教室で は顥骨離断の変形を可及的に抑える目的で，離断額骨健 康皮質部の再植または自家骨移植を用いて即時再建を施 行している5'.

周知のように，エナメル上皮腫の $80 \%$ 以上は下顥骨に 発現する ${ }^{\prime \prime}$ ．下顎骨は独特の弓形態を有し，その再建に ついては特異な配慮を要すると思われる，従って，連続 離断，即時再建後の下枵形態を検討することは甚だ意義 深い課題であり，その研究成果を報告する.

\section{研究 対 象}

\section{A. 内 訳}

対象は九州菌科大学第二口腔外科学教室において下碞
骨連続離断術と同時に，自家肋骨または腸骨の移植ある いは離断影骨健康皮質部の再植による即時再建を施行さ れたエナメル上皮腫患者のうち， 1 年以上の追跡をなし 得た35例である.エナメル上皮腫の彰断は九州歯科大学 口腔病理学教室の病理組織診により決定された。

対象35例の内訳は表 1 亿示すように，男性22例. 女性 13例で，年令は 9 才から76才に亘っていた．腫煌の存在 部位は下頻前歯部から下頡頭部まで多岐に及んだ、從っ て，下顎骨の離断部位も症例毎に様々であったので，便 宜上その範囲を 4 型に分類した。すなおち図 1 亿示すよ うに，池尻らの分類 $(1968)^{5}$ 亿従って，頡骨離断の範 囲がオトガイ部を中心とするものをI型，小大田娄の下 頻体部に限局するものを II 型，てれょり更に下䫟角部に 広がるものを林型とし，林型に下類頭離断を含むものを IV型とした. 分類の結果, I 型は 8 例, II 型は 7 例, III 型は 6 例，IV型は14例であった．下頡再建に用いた骨別 では，自家肋骨または腸骨を移植されたもの（以下，移 植群）は21例で，離断頡骨の健康皮質部を再植されたも

の (以下, 再植群) は14例であった。

術後経過年数は最短 1 年, 最長 13 年 11 力 10カ月であった。

\section{B. 手術々式}

各 4 型とも，皮切および歯肉緣部粘膜切開を加えて， 腫瘍を完全に摘出するよう健康部において骨切術を行 い, 顥骨を連続離断した.ただし，IV型の皮切は III 型と 同様のもので, 下頻頭の離断は盲目的に操作した。

腫場が崡槽骨部之㖪質の一部に限局し下縁皮質部にま で及んでいない場合には，髄質皮質境界部で頡骨を横切 し，さらに皮質内面を骨バーで樋状に削除して腫煌細胞 の㛩底的除去を図った後に，摘出母床へ再植した．

腫瘍が皮質に及んでいる場合や，上述の腫瘍の徹底的 除去後の桶状皮質骨片が菲薄になる場合には，自家骨移 植を行った。 I 型に対しては, Millard ら $(1967)^{71}$ が 発表した Bent Rib Graft に準じて, 離断擷骨の下縁 彎曲長に相当する長さの第 8 肋骨片を採取し, 頻骨に類 似した彎曲を与えて移植した，その際，彎曲の付与を容 易にするため, 採取肋骨内側面に骨バーで縌の切れ込み を加え，また肋骨髄腔内に骨片より約 $2 \mathrm{~cm}$ 長めの直径 $3 \mathrm{~mm}$ の不銹鎆線を插入して，乙れを肋骨と共に曲げ 
Tab. 1 Subjects Index

\begin{tabular}{|c|c|c|c|c|c|c|}
\hline Case & $\begin{array}{l}\text { Age } \\
\text { Yrs }\end{array}$ & Sex & $\begin{array}{c}\text { Operation } \\
\text { Type * }\end{array}$ & $\begin{array}{l}\text { Applied } \\
\text { Bone }\end{array}$ & $\begin{array}{c}\text { Follow up } \\
\text { Yrs }\end{array}$ & $\begin{array}{l}\text { period } \\
\text { Mo }\end{array}$ \\
\hline $1 \mathrm{~S} \mathrm{~S}$ & 23 & $\mathbf{M}$ & $\mathrm{I}$ & $\mathrm{Rib}$ & 3 & 1 \\
\hline $2 \mathrm{MN}$ & 50 & $\mathbf{M}$ & " & " & 4 & 10 \\
\hline $3 \mathrm{~K} \mathrm{I}$ & 54 & $\mathbf{M}$ & " & " & 4 & \\
\hline $4 \mathrm{HT}$ & 53 & $\mathrm{~F}$ & " & Replant** & 13 & 11 \\
\hline $5 \mathrm{FN}$ & 50 & $\mathrm{~F}$ & " & " & 5 & 3 \\
\hline $6 \mathrm{~K} \mathrm{I}$ & 65 & $\mathbf{M}$ & " & "I & 4 & 7 \\
\hline $7 \mathrm{~K} \mathrm{Y}$ & 39 & $\mathbf{M}$ & " & " & 4 & \\
\hline $8 \mathrm{~N} \mathrm{I}$ & 33 & M & " & $"$ & 4 & 10 \\
\hline $9 \mathrm{~S} \mathrm{~K}$ & 39 & $\mathbf{M}$ & II & Ilium & 8 & \\
\hline $10 \mathrm{HY}$ & 39 & $\mathrm{M}$ & $"$ & "I & 7 & \\
\hline $11 \mathrm{SM}$ & 17 & $\mathbf{M}$ & " & " & 4 & \\
\hline $12 \mathrm{EN}$ & 24 & $\mathbf{M}$ & " & $" 1$ & 2 & 4 \\
\hline $13 \mathrm{MM}$ & 21 & $\mathrm{~F}$ & " & " & 8 & 2 \\
\hline $14 \mathrm{~B} \mathrm{O}$ & 37 & $\mathbf{M}$ & $" 1$ & Replant** & 1 & 10 \\
\hline $15 \mathrm{~S} \mathrm{Y}$ & 24 & $\mathrm{~F}$ & $"$ & " & 1 & \\
\hline $16 \mathrm{KE}$ & 34 & $\mathrm{~F}$ & III & Ilium & 11 & 5 \\
\hline $17 \mathrm{NM}$ & 22 & $\mathbf{M}$ & " & $"$ & 9 & 6 \\
\hline $18 \mathrm{R} \mathrm{T}$ & 68 & $\mathbf{M}$ & " & " & 3 & \\
\hline $19 \mathrm{KM}$ & 60 & $\mathbf{M}$ & $"$ & " & 1 & \\
\hline 20 I N & 62 & $\mathbf{M}$ & " & Replant ${ }^{* * *}$ & 3 & 4 \\
\hline $21 \mathrm{~K} \mathrm{~K}$ & 42 & $\mathbf{M}$ & " & $" 1$ & 1 & 5 \\
\hline $22 \mathrm{AE}$ & 44 & $\mathrm{~F}$ & IV & Ilium & 13 & 3 \\
\hline $23 \mathrm{R} \mathrm{S}$ & 39 & $\mathrm{~F}$ & " & " & 8 & \\
\hline $24 \mathrm{~T} \mathrm{H}$ & 55 & $\mathbf{M}$ & " & " & 6 & 6 \\
\hline $25 \mathrm{YM}$ & 30 & $\mathrm{~F}$ & " & $"$ & 6 & \\
\hline $26 \mathrm{H} \mathrm{I}$ & 39 & $\mathbf{F}$ & " & " & 5 & \\
\hline $27 \mathrm{HF}$ & 76 & $\mathbf{M}$ & " & $"$ & 4 & \\
\hline $28 \mathrm{AM}$ & 16 & $\mathbf{M}$ & " & " & 3 & 5 \\
\hline $29 \mathrm{~S} \mathrm{~K}$ & 18 & $\mathrm{~F}$ & " & " & 2 & 1 \\
\hline $30 \mathrm{YN}$ & 9 & $\mathbf{M}$ & " & " & 6 & 9 \\
\hline $31 \mathrm{YH}$ & 16 & $\mathrm{~F}$ & " & Replant**: & 3 & 5 \\
\hline $32 \mathrm{YM}$ & 31 & M & " & " & 3 & \\
\hline $33 \mathrm{TA}$ & 34 & $\mathbf{M}$ & " & " & 3 & \\
\hline $34 \mathrm{CH}$ & 17 & $\mathrm{~F}$ & $"$ & " & 1 & 4 \\
\hline $35 \mathrm{YH}$ & 16 & $\mathrm{~F}$ & " & " & 2 & \\
\hline
\end{tabular}

*See Fig. $1 \quad * *$ Replantation of healthy cortex of mandible

て下頻弓に近い彎曲を与えると同時に，その突出鋼線を 母床骨断端に插入し，各骨端にそれぞれドリルで小孔を あけ直径 0.5mm の不銹鍊線で結秋し，彎曲の維持と骨 片の固定を図った、II型，III型およびIV型に対しては， 腸骨より採取した骨片を移植補填した。すなわ方，I型

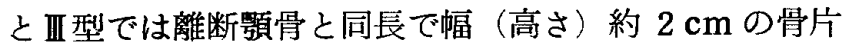

を採取補填し，IN型に対しては下影枝（後縁外側）下 $1 / 2$ までの長さの骨片を採取補填し，筋突起や下䫫頭の再建 は行わなかった。

術後 $2 \sim 3$ 力月間は䋶間固定または池尻式顎外ピン固 定装置 ${ }^{8}$ を適用した。

全例の手術は気管内插管全身麻醉下に施行された。 
$M$ 点：仮想オトガイ点. $S S$ 軸と下䈯下縁の交点.

$\mathrm{C}^{\prime}$ 点; $\mathrm{C}$ 点汃ら下した垂線の $\mathrm{S} \mathrm{S}$ 軸上の点. $\mathrm{Cr}$ 点 からのものを $\mathrm{C}^{\prime} \mathrm{r}$ 点, $\mathrm{Cl}$ 点からのものを $\mathrm{C}^{\prime} 1$ 点とする.

$A^{\prime}$ 点; $A$ 点から下した垂線の $S S$ 軸上の点. $A r$ 点 からのものを $\mathrm{A}^{\prime} \mathrm{r}$ 点, $\mathrm{A} 1$ 点からのものを $\mathrm{A}^{\prime} 1$ 点とする.

以上のうち，S S 軸と $\mathrm{C}$ 点を設定する基準の前鼻棘・ 上颚正中槰合あるいは下瀕頭の像の不明確なるのは検定 の対象より除外した. その結果, 研究対象35例中25例が 対称性試験の検定対象となった。

計測項目之計測方法：

下頼頭間距離比; $\mathrm{CC}^{\prime}-\mathrm{R}=\mathrm{Cr}-\mathrm{C}^{\prime} \mathrm{r} / \mathrm{Cl}-\mathrm{C}^{\prime} 1$ $\times 100$

仮想下頼角間距離此; $\mathrm{AA}^{\prime}-\mathrm{R}=\mathrm{Ar}-\mathrm{A}^{\prime} \mathrm{r} / \mathrm{Al}$

$$
-A^{\prime} 1 \times 100
$$

下罰頭垂直距離比; $\mathrm{C}^{\prime} \mathrm{M}-\mathrm{R}=\mathrm{C}^{\prime} \mathrm{r}-\mathrm{M} / \mathrm{C}^{\prime} 1-\mathrm{M}$ $\times 100$

仮想下影枝体長比； $C^{\prime} A^{\prime}-R=C^{\prime} r-A^{\prime} r / C^{\prime} 1$

$$
-A^{\prime} 1 \times 100
$$

仮想下頼的比 ; $\angle \mathrm{A}-\mathrm{R}=\angle \mathrm{Ar} \angle \angle \mathrm{A} 1 \times 100$

( $\angle \mathrm{A}$ は点Aに抢ける接線の交角の角度)

すなわち，5項目いずれも左側の計測值を 100 とする 右側の換算値を求めた.

3. 予備試験

対称性試験の実施に先立ち, 健康成人 2 名（41才男性 之40才女性) および研究対象中の 2 例 (症例 21 之症例 35 ) の計 4 例を対象として，短期間に再撮影されたオルソパ ントモグラムを用いて，オルソパントモグラムの規格性 ならびに対称性試験の信頼性を検討した。

すなわち，41才男性では 2 日の間隔で，40才女性では 2 カ月の間隔で再撮影された 2 枚のオルソパントモグラ

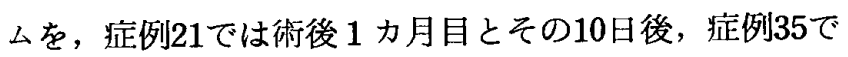
は術後 1 カ月目とその 7 日後および14日後のオルンパン トモグラムを用いて，それぞれの重ね合せ像の一致の程 度を検討し，またそれぞれに対称性試験を施行し，成績 を比較検討した。

以上の予備試験に打ける対称性試験の成績の変動の最 大值を，対称性試験の測定誤差と見做した。

\section{4. 対照試験}

健康で肉眼的観察においても額顔面形態に異常を見出 し得ない成人（17才〜73才）男女それぞれ10名の計 20 名 のオルソパントモグラムに対称性試験を施行し, 本試験
の正常変動範囲を求めた.

\section{5. 対称性試験の正常範囲の算出}

対照 20 名の対称性試験で得られた 5 項目の各測定值中 それぞれ最高值と最低值を除外して, 残った数值を正常 変動範囲とした。

さらに，予備試験で確認された測定誤差を 5 項目の各 正常変動範囲に加減して, 得られた数值をそれぞれの正 常範用として取扱った。

\section{研 究 成}

\section{A. 肉眼的観察による判定成績}

対象35例の下䅡顔面形態について 3 検者で検定した結 果は表 2 に示すとおりであった． 3 検者の判定は全例一

Tab. 2 Result in Gross Evaluation of Postoperative Mandibular Appearance

\begin{tabular}{cccccccc}
\hline \hline \multirow{2}{*}{ Type } & \multicolumn{2}{c}{ Total No. } & \multicolumn{2}{c}{$\begin{array}{l}\text { Transplant. } \\
\text { Group }\end{array}$} & \multicolumn{2}{c}{$\begin{array}{l}\text { Replant } \\
\text { Group }\end{array}$} \\
& Good & Poor & Good & Poor & \multicolumn{2}{c}{ Good } & Poor \\
\hline I & $8 / 8$ & $0 / 8$ & $3 / 3$ & $0 / 3$ & $5 / 5$ & $0 / 5$ \\
II & $6 / 7$ & $1 / 7$ & $5 / 5$ & $0 / 5$ & $1 / 2$ & $1 / 2$ \\
II & $1 / 6$ & $5 / 6$ & $0 / 4$ & $4 / 4$ & $1 / 2$ & $1 / 2$ \\
IV & $5 / 14$ & $9 / 14$ & $2 / 9$ & $7 / 9$ & $3 / 5$ & $2 / 5$ \\
\hline Male & $13 / 22$ & $9 / 22$ & $8 / 14$ & $6 / 14$ & $5 / 8$ & $3 / 8$ \\
Female & $7 / 13$ & $6 / 13$ & $2 / 7$ & $5 / 7$ & $5 / 6$ & $1 / 6$ \\
\hline \hline Total & $20 / 35$ & $15 / 35$ & $10 / 21$ & $11 / 21$ & $10 / 14$ & $4 / 14$ \\
$(\%)$ & $(57.1)$ & $(42.9$ & & & & \\
\hline
\end{tabular}

致した結果であった。

形態良好と判定された症例は35例中 20 例 $(57.1 \%)$ で， 残る15例 $(42.9 \%)$ は何らかの変形があり不良と判定さ れた。

この成績は手術法型別により異り，I型では 8 例中 8 例 $(100 \%)$ が良好，II 型では 7 例中 6 例 $(85.7 \%)$ が 良好之判定されたのに対し，II型では 6 例中 1 例 $(16.7$ $\%$ ）のみ，IV型では14例中 5 例 $(35.7 \%)$ が良好之判定 されたにすぎなかったすなわち，I型，II型，次いで IV 型の順に形態良好な症例が多く， III型は最も悪い成績 で 6 例中 5 例 $(83.3 \%)$ が形態不良と判定された。

移植群と再植群とに分けた適用骨別では，I 型におい ては差はなく，II 型においては移植群の 5 例中 5 例 $(100$ $\%)$ が良好に対し，再植群の 2 例中 1 例 $(50 \%)$ は不良 であったＩII型に扔いては，移植群の 4 例全例 (100\%) 
が不良に対し，再植群の 2 例中 1 例（50\%）は良好であ った・またI型においても，移植群の 9 例中 2 例（22.2 \%) が良好と判定されたのに対し，再植群では 5 例中 3 例 $(60 \%)$ が良好であった．総合すると，移植群の 21 例 中10例 $(47.6 \%)$ が良好之判定され, 再植群では14例中 10例 $(71.4 \%)$ が良好と判定された.

性別または年令別の成績の差は特に見出し得なかっ た。

形態不良例15例のそれぞれの変形内容は表 3 亿示すと おりで，II型不良例の 5 例中 4 例 $(80 \%)$ は煩部の扁平 化と下頡角の直線化を，IV 型不良例の 9 例中 8 例（88.9 $\%$ ）は開口時の下頧偏位を，さらにうち 7 例 $(77.8 \%)$ は煩部の扁平化を示していた．変形の内容別頻度順に整 理してみると，図 3 に示すように，煩部の扁平化が15例 中11例 $(73.3 \%)$ に見られ最も多く，次いで開口時の

Tab. 3 Appearrance of deformities in 15 cases

\section{Case Type Bone Contents of deformities}

\begin{tabular}{|c|c|c|c|}
\hline 14 & II & Cortex & $\begin{array}{l}\text { Shortening of mandibular } \\
\text { body }\end{array}$ \\
\hline 16 & III & Ilium & Submandibular hollow \\
\hline 17 & " & "I & $\begin{array}{l}\text { Flat cheek and linear } \\
\text { angle }\end{array}$ \\
\hline 18 & " & $" 1$ & $"$ \\
\hline 19 & " & " & " \\
\hline 21 & " & Cortex & $" 1$ \\
\hline 22 & IV & Ilium & $\begin{array}{l}\text { Flat chee, deviation and } \\
\text { shortening }\end{array}$ \\
\hline 23 & " & $" 1$ & $\begin{array}{l}\text { Flat cheek and opening } \\
\text { deviation }\end{array}$ \\
\hline 24 & $" 1$ & $" 1$ & $\begin{array}{l}\text { Shortening and opening } \\
\text { deviation }\end{array}$ \\
\hline 25 & $" 1$ & $" \prime$ & $\begin{array}{l}\text { Flat cheek and opening } \\
\text { deviation }\end{array}$ \\
\hline 26 & " & $"$ & $"$ \\
\hline 27 & " & " & " \\
\hline 28 & $"$ & $"$ & $"$ \\
\hline 33 & " & Cortex & $\begin{array}{l}\text { Flat cheek and deviation } \\
\text { in opening }\end{array}$ \\
\hline 35 & $" 1$ & $" \prime$ & Submandibular hollow \\
\hline
\end{tabular}

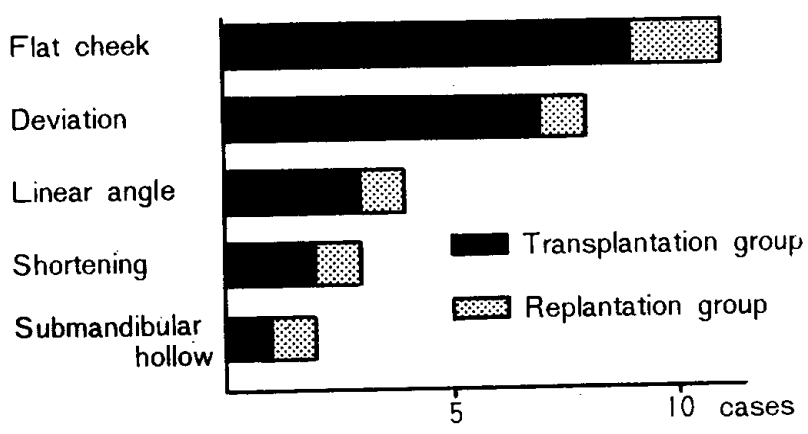

Fig. 3 Proportion of deformity type in $\mathbf{1 5}$ cases.

下顎偏位が 8 例 $(53.3 \%)$ 亿，下類角の直線化が 4 例 (26.7\%) 亿，下影体部の短縮が 3 例 $(20 \%)$ 亿，顥下 部の宿凹が 2 例 $(13.3 \%)$ に見られた。

それぞれの変形内容が異なるために，15例を変形度順 に評価するのは困難であるが，下影形態の左右不均衡が 最も著しいと思われた症例は症例 22 と23の 2 例（図 4 と 5 ）で，ともにN型腸骨移植例であった。 2 例とも頻部 の扁平化と下頻偏位がその変形の主内容であり, 特に開 口時に顕著であった．しかし写真（図4 と 5) に明らか なように，醜悪とは形容出来ない程度の変形にとどまっ ていた。

一方, 症例33は閉口時形態には特に指摘される変形を 有していなかったが，最大開口時の下顎偏位が認められ たため，不良と判定された（図6)。

B . オルソパントモグラムによる対称性試験の成績

1. 予備試験の成績

オルソパントモグラムの規格性ならびに対称性試験の 信頼性を検定するための予備試験の結果は表 4 亿示すと おりであった。また，各症例の複写図を S S 軸とM点を 基準に重ね合せた結果は図 7 に示すとおりであった。

すなわち，各症例とも測定值の誤差は最大 \pm 3 の範囲 内の変化にとどまり，また重和合せ図においてもかなり の一致が示された．とのととより，オルソパントモグラ ムにはかなりの規格性が期待でき，且つ対称性試験も土 3 の誤差で信頼性を有するととが伺われた。

2. 対照試験の成績

顔貌形態に異常のない男女計20名のオルソパントモグ ラムに対称性試験を行った結果は表 5 に示すとおりであ った。

5 項目それぞれの成績のうち, 最上限値および最下限 值（いずれも表 5 中で下線を付した数值）を除いて求め た正常変動範囲は， $91 \leqq \mathrm{CC}^{\prime}-\mathrm{R} \leqq 106,87 \leqq \mathrm{AA}^{\prime}-\mathrm{R}$ 
$\leqq 106, \quad 91 \leqq C^{\prime} M-R \leqq 106, \quad 94 \leqq C^{\prime} A^{\prime}-R \leqq 110,95$ $\leqq \angle \mathrm{A}-\mathrm{R} \leqq 103$ であった.

3. 対称性試験の正常範囲

以上の $1 \cdot 2$ の成績, すなわち正常変動範囲に最大誤 差範囲を加減して求めた 5 項目のそれぞれの正常範囲

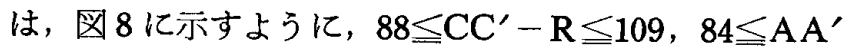
$-R \leqq 109,88 \leqq C^{\prime} M-R \leqq 109,91 \leqq C^{\prime} A^{\prime}-R \leqq 113$, $92 \leqq \angle \mathrm{A}-\mathrm{R} \leqq 106$ であった.

\section{4. 対称性試験の成績}

25例（移植群14例と再植群11例）を対象に対称性試験 を施行した結果は表 6 に示すとおりであった.

計測項目別では, $\angle A-R, A A^{\prime}-R$ と $C^{\prime} A-R$, $\mathrm{CC}^{\prime}-\mathrm{R}, \mathrm{C}^{\prime} \mathrm{A}^{\prime}-\mathrm{R}$ の順に正常範囲外数值が多く見ら れた。すなわち， $\angle \mathrm{A}-\mathrm{R}$ は15例， $\mathrm{AA}^{\prime}-\mathrm{R}$ と $\mathrm{C}^{\prime} \mathrm{A}^{\prime}$ $-\mathrm{R}$ はそれぞれ11例, $\mathrm{CC}^{\prime}-\mathrm{R}$ は 5 例, $\mathrm{C}^{\prime} \mathrm{M}-\mathrm{R}$ は 4 例に正常範囲外の異常值が見られた.

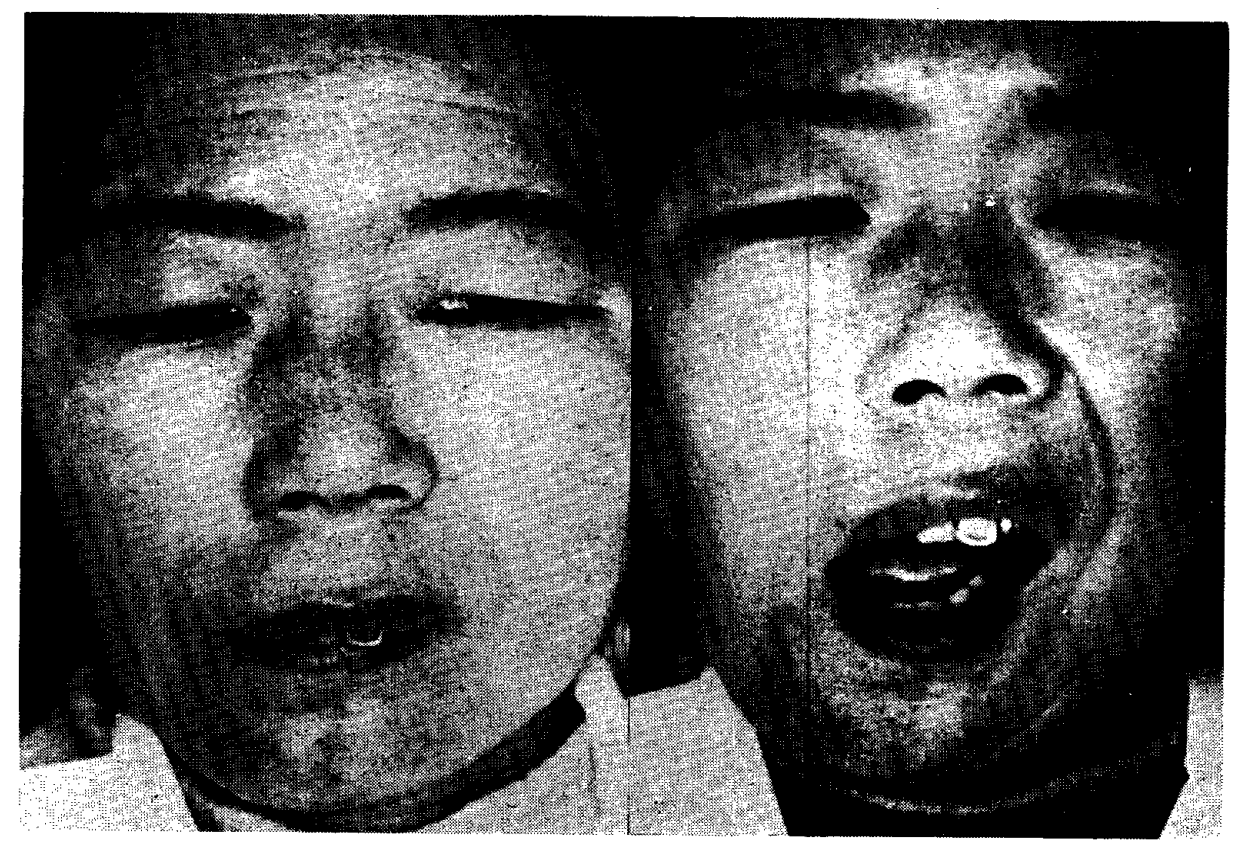

Fig. 4 Appearance of the most severe deformed case.

(Case No. 22 operated type IV with iliac transplantation) The flat cheek, mandibula deviation and shortening revealed on operated right side, these were conspicuous during function.
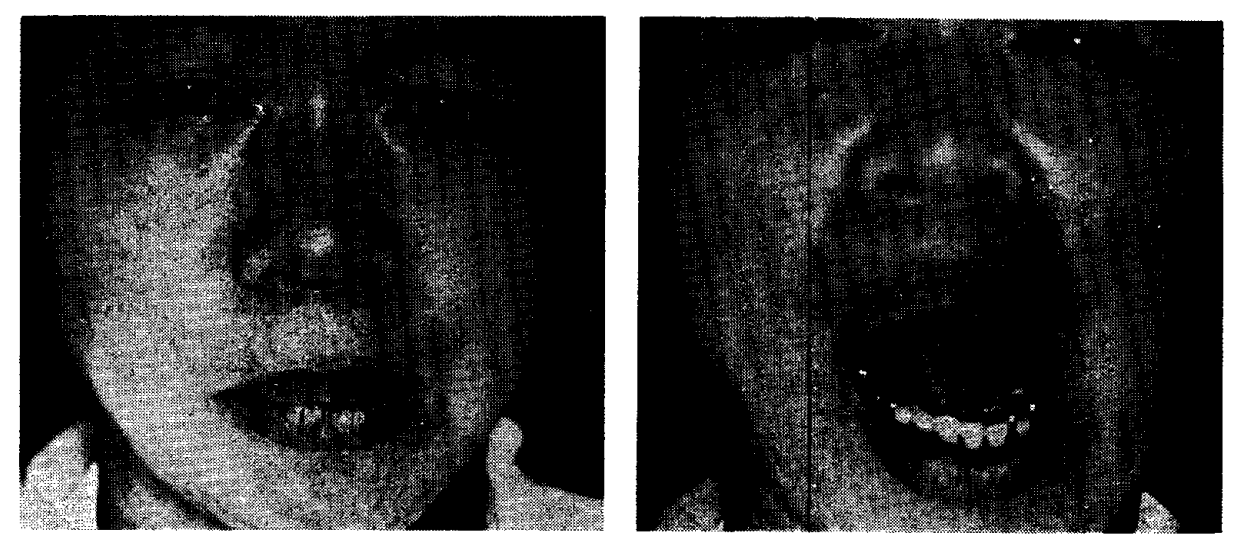

Fig. 5 Appearance of the another severe deformed case. (Case No. 23 operated type IV with iliac transplantation) The flat cheek revealed on operated left side during rest, and mandibular deviation during function. 

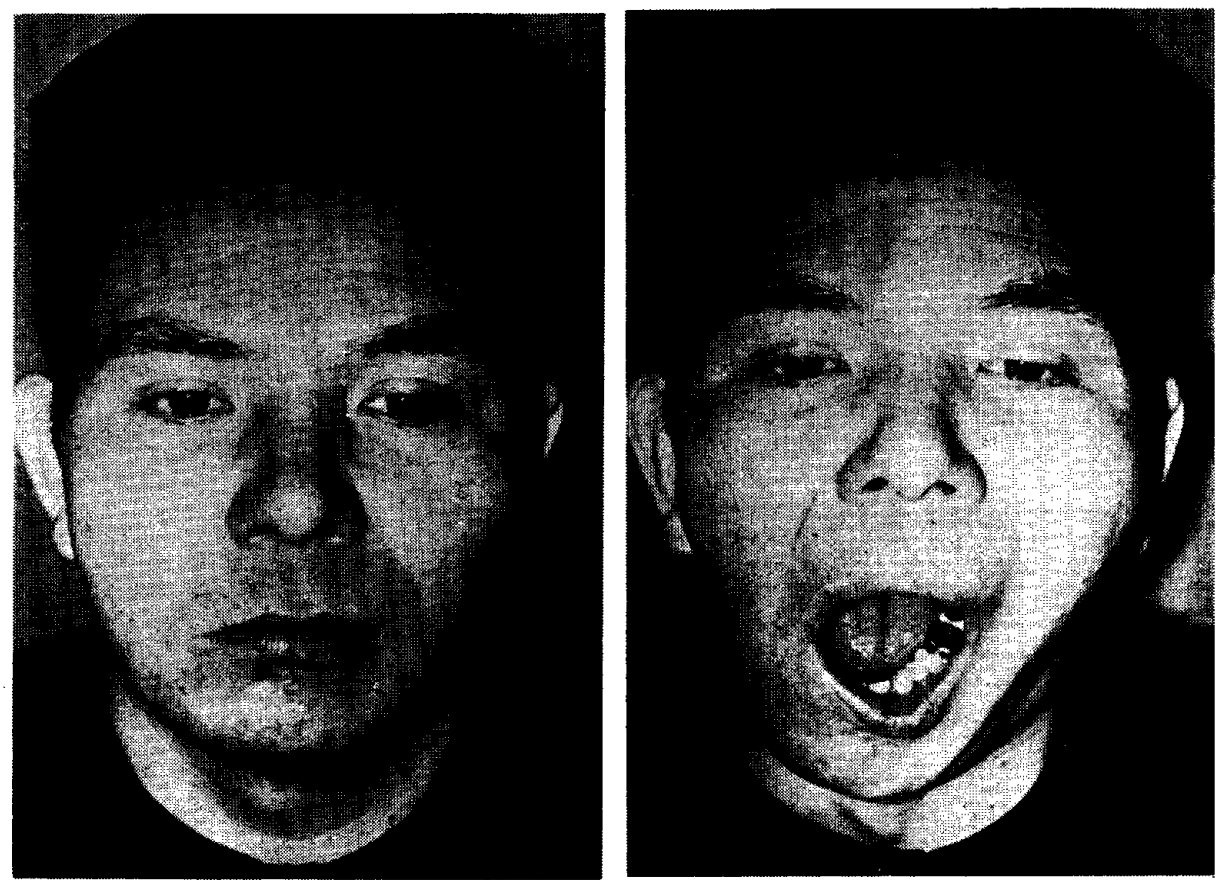

Fig. 6 Appearance of Case No. 33 operated type IV with cortex replantation, classified in Poor-Form Group. The mandibular contour reveals good form during rest, however the mandibular deviation toward operated side and flat cheek during function.

Tab. 4 Results of Preliminary Examination

\begin{tabular}{|c|c|c|c|c|c|}
\hline Case & $\mathrm{CC}^{\prime}-\mathrm{R}$ & $A A^{\prime}-R$ & $C^{\prime} M-R$ & $C^{\prime} A^{\prime}-R$ & $\angle \mathrm{A}-\mathrm{R}$ \\
\hline TY $41 \mathrm{M}$ & 102 & 100 & 102 & 101 & 104 \\
\hline $\operatorname{Re}-\mathrm{Ex}^{*}$ & 102 & 98 & 102 & 104 & 103 \\
\hline Error & 0 & -2 & 0 & 3 & -1 \\
\hline YH $40 \mathrm{~F}$ & 102 & 99 & 100 & 111 & 99 \\
\hline $\operatorname{Re}-\mathrm{Ex}^{* *}$ & 100 & 100 & 102 & 109 & 98 \\
\hline Error & -2 & 1 & 2 & -2 & -1 \\
\hline No.21 & 103 & 113 & 106 & 123 & 81 \\
\hline $\operatorname{Re}-\mathrm{Ex}^{* * *}$ & 102 & 116 & 105 & 123 & 80 \\
\hline Error & -1 & 3 & -1 & 0 & -1 \\
\hline No.35 & 97 & 96 & 105 & 107 & 102 \\
\hline $\operatorname{Re}-\mathrm{Ex}^{* * * *}$ & 97 & 96 & 108 & 108 & 99 \\
\hline $\operatorname{Re}-\mathbf{E x}^{* * * * *}$ & 97 & 95 & 105 & 107 & 100 \\
\hline Error & 0 & \pm 1 & \pm 3 & \pm 1 & \pm 3 \\
\hline
\end{tabular}

Note : Durations of reexamination $(\mathrm{Re}-\mathrm{Ex})$.

* 2 days ** 2 months ${ }^{* * *} 10$ days **** 7 days **** 14 days 

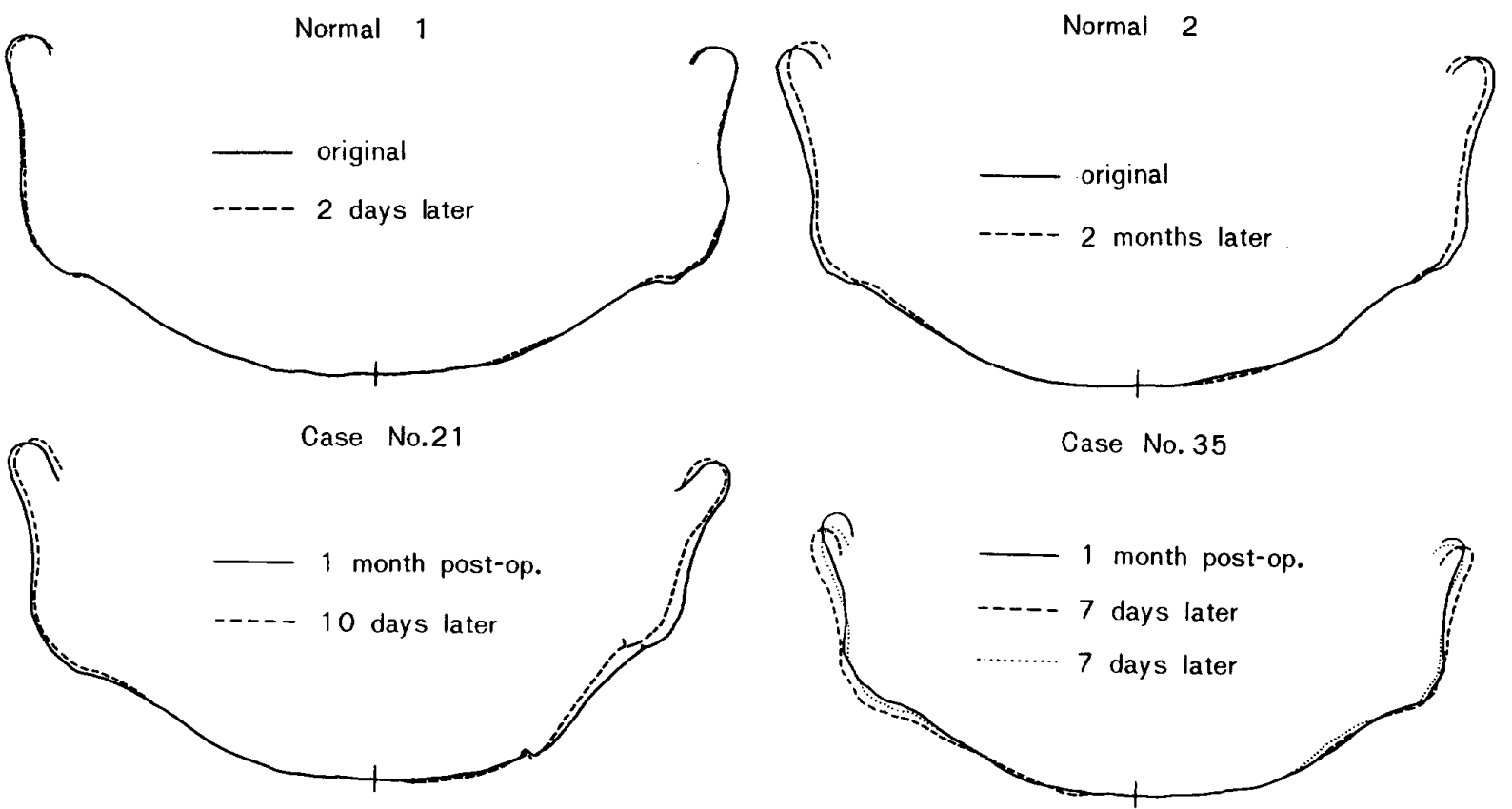

Fig. 7 Sample tracing of preliminary examination.

Tab. 5 Results of Controlled Examination

\begin{tabular}{|c|c|c|c|c|c|}
\hline Case & $C C^{\prime}-\mathrm{R}$ & $A A^{\prime}-R$ & $\mathrm{C}^{\prime} \mathrm{M}-\mathbf{R}$ & $C^{\prime} A^{\prime}-R$ & $\angle \mathrm{A}-\mathrm{R}$ \\
\hline 1 & $\underline{81}$ & 87 & 96 & 104 & 99 \\
\hline 2 & 100 & 98 & 103 & 111 & 97 \\
\hline 3 & 97 & 90 & 105 & 104 & 98 \\
\hline 4 & 104 & 106 & 99 & 96 & 95 \\
\hline 5 & 91 & $\underline{78}$ & 95 & 95 & 101 \\
\hline 6 & 104 & 102 & 109 & 97 & 97 \\
\hline 7 & 92 & 88 & 91 & 110 & 100 \\
\hline 8 & 93 & 96 & 95 & 104 & 100 \\
\hline 9 & 93 & 94 & 96 & 98 & 96 \\
\hline 10 & 106 & 104 & 101 & $\underline{88}$ & 102 \\
\hline 11 & 100 & 102 & 94 & 94 & 99 \\
\hline 12 & 99 & 99 & 98 & 103 & 100 \\
\hline 13 & 103 & 103 & 94 & 99 & 95 \\
\hline 14 & 100 & 105 & 103 & 99 & $\underline{89}$ \\
\hline 15 & 105 & 97 & 102 & 99 & 103 \\
\hline 16 & 100 & $\underline{109}$ & 93 & 106 & 99 \\
\hline 17 & 104 & 93 & 106 & 105 & 111 \\
\hline 18 & 98 & 97 & 93 & 110 & 98 \\
\hline 19 & 101 & 102 & $\underline{90}$ & 106 & 101 \\
\hline 20 & $\underline{108}$ & 100 & 96 & 101 & 101 \\
\hline $\operatorname{Max}^{*}$ & 106 & 106 & 106 & 110 & 103 \\
\hline $\operatorname{Min}^{* *}$ & 91 & 87 & 91 & 94 & 95 \\
\hline
\end{tabular}

Note : Underlined figures are out of account.

* Maximum means the top of normal variety which is accounted by excepting the underlined figure in each heads.

** Minimum means the bottom of normal variety which is accounted as same as Maximum. 


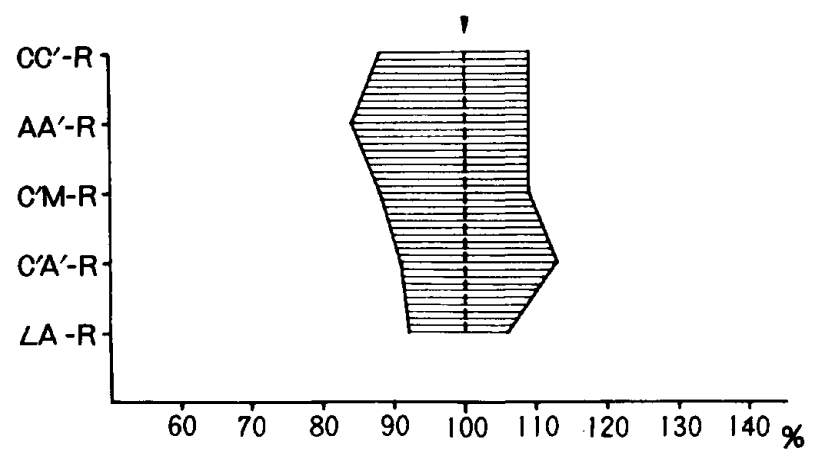

Fig. 8 Normal limits of Symmetry Examination.
個々の症例別では， 5 項目の全てが正常範囲内のもの 7 例, 4 項目が正常範囲内のもの 2 例, 3 項目が正常範 囲内のもの 8 例, 2 項目が正常範囲内のもの 5 例, 1 項 目が正常範囲内のもの 2 例で, 5 項目の全てが正常筑囲 外のものは 1 例であった.

ただし，症例21は手術側下䅡角部の変形が著明なため に(図13と16参照)， $\mathrm{AA}^{\prime}-\mathrm{R}$ と $\mathrm{C}^{\prime} \mathrm{A}^{\prime}-\mathrm{R}$ を算出で きなかった。

手術法の型別に検討した結果は図 9 のようであった (但し, 症例21を除く).

$\mathrm{I}$ 型では $\mathrm{AA}^{\prime}-\mathrm{R}$ において 1 例（症例 6 ）が 129 と

Tab. 6 Results of Symmetry Examination

\begin{tabular}{|c|c|c|c|c|c|c|}
\hline Case & $\mathrm{CC}^{\prime}-\mathrm{R}$ & $A A^{\prime}-R$ & $C^{\prime} M-R$ & $C^{\prime} A^{\prime}-R$ & $\angle \mathrm{A}-\mathrm{R}$ & No. of Out \\
\hline 1 & 91 & 90 & 105 & 99 & 99 & 0 \\
\hline 2 & 98 & 97 & 100 & 101 & 99 & 0 \\
\hline 3 & 103 & 87 & 101 & 91 & $\underline{116}$ & 1 \\
\hline 4 & 100 & 88 & 104 & $\underline{85}$ & $\underline{120}$ & 2 \\
\hline 5 & 103 & 102 & 97 & 94 & 105 & 0 \\
\hline 6 & 109 & 129 & 100 & 106 & $\underline{87}$ & 2 \\
\hline 8 & 93 & 112 & 106 & 111 & $\underline{91}$ & 2 \\
\hline 9 & 100 & 96 & 95 & 108 & 103 & 0 \\
\hline 12 & 100 & $\underline{83}$ & 101 & $\underline{86}$ & $\underline{130}$ & 3 \\
\hline 13 & 100 & $1 \overline{00}$ & 100 & 105 & $\overline{104}$ & 0 \\
\hline 14 & 101 & 87 & 102 & $\underline{85}$ & $\underline{150}$ & 2 \\
\hline 16 & 97 & $\underline{71}$ & 103 & 131 & $\underline{108}$ & 3 \\
\hline 17 & $\underline{113}$ & $\overline{90}$ & 98 & $\overline{136}$ & $\overline{93}$ & 2 \\
\hline 19 & $\underline{85}$ & $\underline{120}$ & 89 & $\underline{66}$ & $\underline{78}$ & 4 \\
\hline 20 & 95 & 74 & 97 & 91 & $\underline{125}$ & 2 \\
\hline 21 & 106 & $*$ & 100 & * & $\overline{63}$ & 3 \\
\hline 22 & 97 & 85 & 95 & 95 & 106 & 0 \\
\hline 24 & 106 & $\underline{115}$ & 101 & 110 & $\underline{80}$ & 2 \\
\hline 28 & 88 & 77 & 85 & $\underline{46}$ & 131 & 4 \\
\hline 29 & $\underline{114}$ & 110 & 118 & 111 & 92 & 3 \\
\hline 30 & 100 & 98 & 109 & $\underline{118}$ & 97 & 1 \\
\hline 31 & 98 & 99 & 95 & $\overline{100}$ & 101 & 0 \\
\hline 33 & 71 & $\underline{79}$ & $\underline{77}$ & $\underline{43}$ & $\underline{150}$ & 5 \\
\hline 34 & $\overline{103}$ & $\overline{86}$ & $\underline{87}$ & $\overline{92}$ & $\overline{120}$ & 2 \\
\hline 35 & $\underline{86}$ & 91 & 93 & $\underline{118}$ & $\underline{86}$ & 3 \\
\hline $\begin{array}{l}\text { No. of } \\
\text { Out }\end{array}$ & 5 & 11 & 4 & 11 & 15 & \\
\hline
\end{tabular}

Note : Underlined figures are out of normal limits.

* These could not account. 

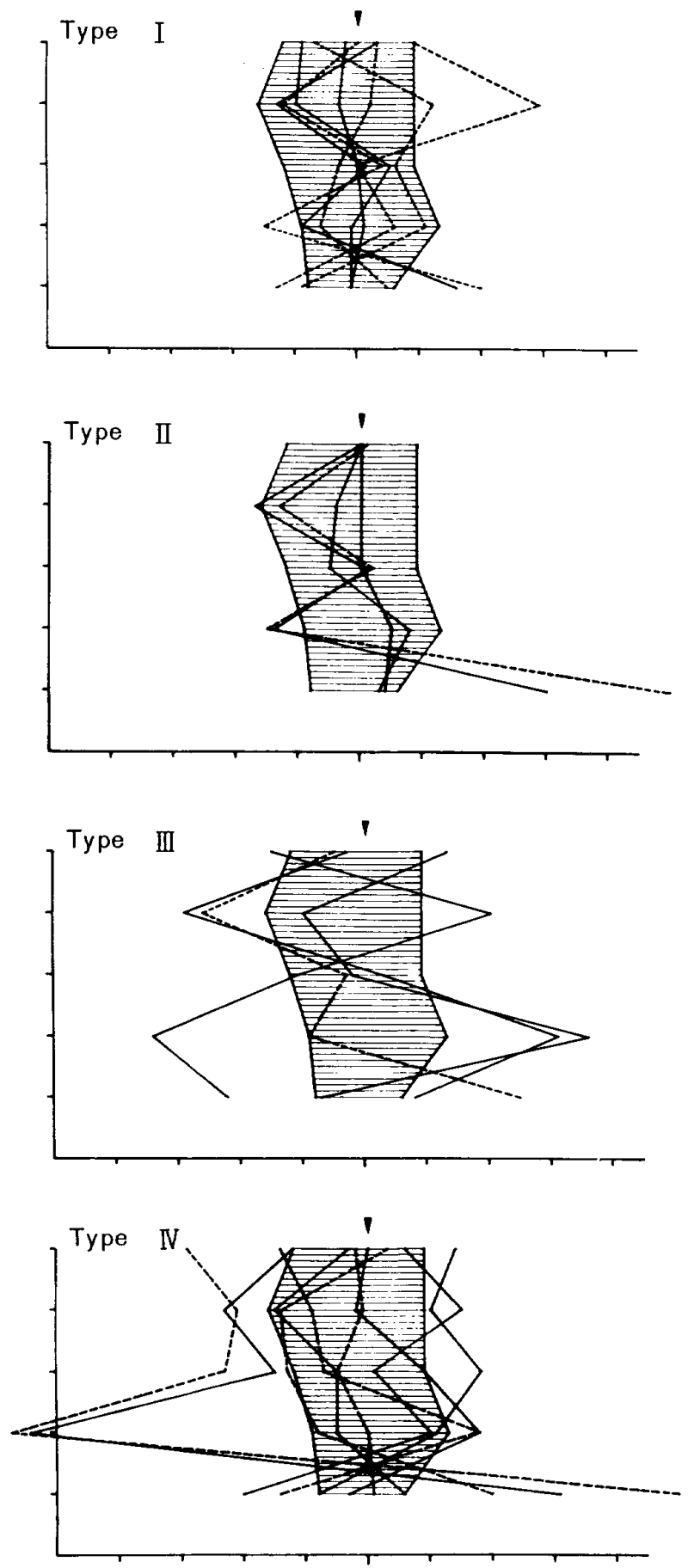

Fig. 9 Analysis of Symmetry Examination in four operation types.

Solid line : transpanted group.

Broken line: replanted group.

かなりの変動を示した他は著しい異常値は認められなか った.

II 型では $\angle \mathrm{A}-\mathrm{R}$ において 2 例（症例12 と14）が 130 と 150 というかなり大きな異常值を示した。
III型では $\mathrm{AA}^{\prime}-\mathrm{R}$ において 3 例, $\mathrm{C}^{\prime} \mathrm{A}^{\prime}-\mathrm{R}$ におい て 3 例, $\angle A-R$ に扔いて 2 例がかなりの異常值を示し た。

IV型では 2 例（症例28と43）が殆んどの項目において かなり著しい異常值を示し，殊に $\mathrm{C}^{\prime} \mathrm{A}^{\prime}-\mathrm{R}$ と $\angle \mathrm{A}$ Rにおいて顕著であった。

すなわち，IV型，臬型，次いでII 型の順に異常值が多 くみられ，I型において最も少かった。

適用骨別では，やはり図9に示されるように，I型で は再植群に，NV型では移植群の方により多く異常值を示 す症例が見られ，II型および血型では特に差はなかった。

III型と IV 型の症例を対象として，手術部位の左右側別 に検討した結果は図10のようであった。

右側手術群では， $\angle \mathrm{A}-\mathrm{R}$ は 100 以上,他の 4 項目は 100 以下の数值を示す傾向にあり, 左側手術群では逆に， $\angle \mathrm{A}-\mathrm{R}$ は 100 以下, 他の 4 項目は 100 以上の数值を示 す傾向にあり，殊に $\mathrm{C}^{\prime} \mathrm{A}^{\prime}-\mathrm{R}$ および $\angle \mathrm{A}-\mathrm{R}$ におい て明らかであっだ。

次に，対称性試験の成績を形態良好群と不良群とに分 けて検討した結果は図11のようであった（但し，症例21 は除く).
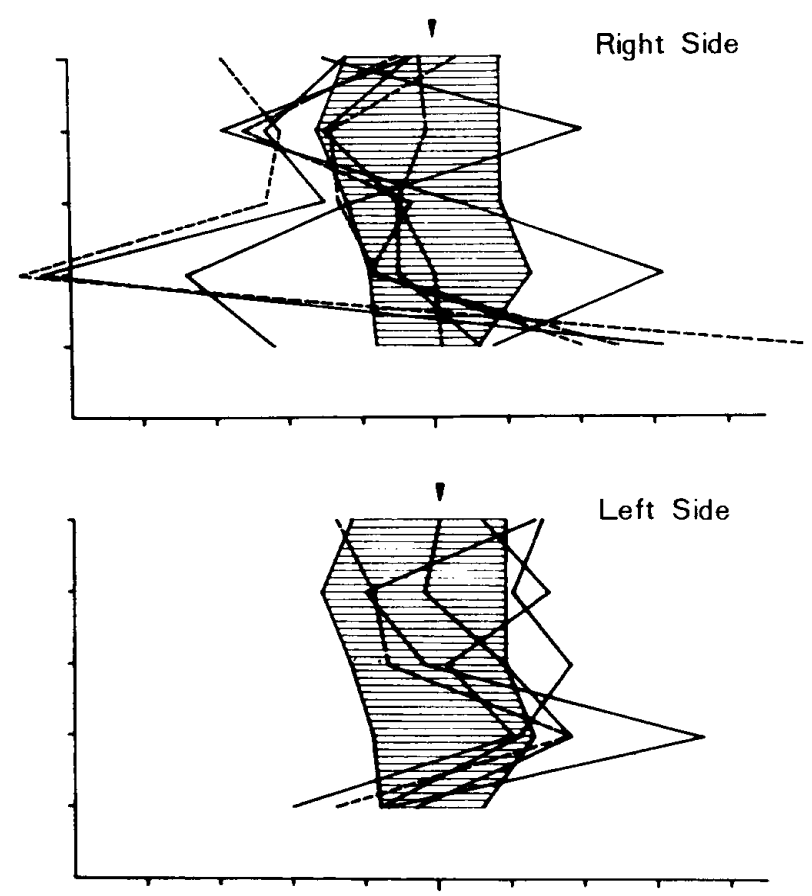

Fig.10 Analysis of Symmetry Examination in parting the right and left side of operation site.

Meaning of lines are sa me as Fig.9. 

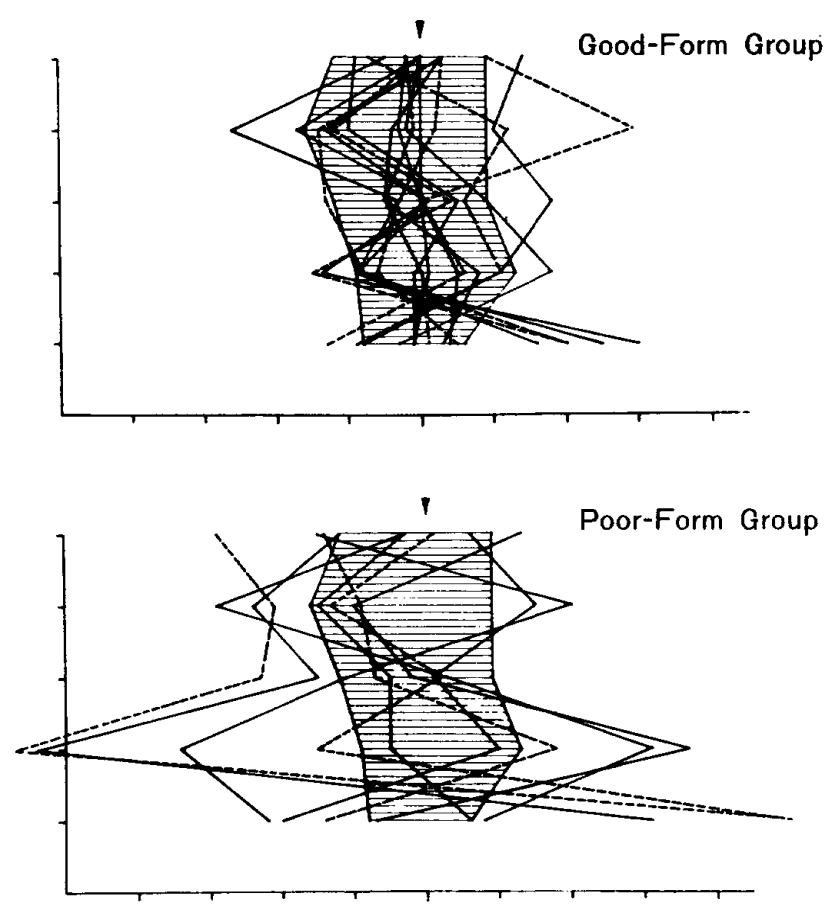

Fig.11 Analysis of Symmetry Examination in result of gross evaluation of appearance.

Meaning of lines is same as Fig. 9.
形態良好群の15例では， $\angle \mathrm{A}-\mathrm{R}$ 次いで $\mathrm{AA}^{\prime}-\mathrm{R}$ に 異常值を見るが著しい数值はなく，15例中 6 例は 5 項目 の全てが正常範用内であった.一方, 不良群では殆んど の症例にかなりの異常値が見られ，5項目の全てが正常 範囲内のものは 1 例（症例22）のみであった．検討対象 より除外した症例 $21 も \mathrm{AA}^{\prime}-\mathrm{R}, \mathrm{C}^{\prime} \mathrm{A}-\mathrm{R}$ ，および $\angle \mathrm{A}-\mathrm{R}$ に異常值を呈していた。

\section{5. 経時的変化}

術後, 経時的にオルソパントモグラムを撮影して対称 性試験を行い得た 8 例（症例 $2 ， 8 ， 13,17,21,30$,

$34 ， 35 ） の \angle A-R$ の推移を検討した結果は図12に示 すようであった。

術後 1 年以内の追跡を行い得た 4 例では, $2 \sim 8$ カ月 と間隔は異なるが，かなりの変化が認められた。一方， 他の 4 例も含めた術後 8 力月目以降の成績においては， 小さな範囲の変化にとどまり安定していた。

S S 軸とM点を基準に重的合せた図を検討すると，図 13 亿示すように，やはり術後 1 年以内の 4 例の像にはか なりの不一致が見られた。

すなわち, 症例21（左側血型再植群）の術後 1 力月目 と 2 カ月目では手術側下影角部（再植骨後端接合部）に おける変形が認められる。しかし 2 力月目と 1 年 5 カ月

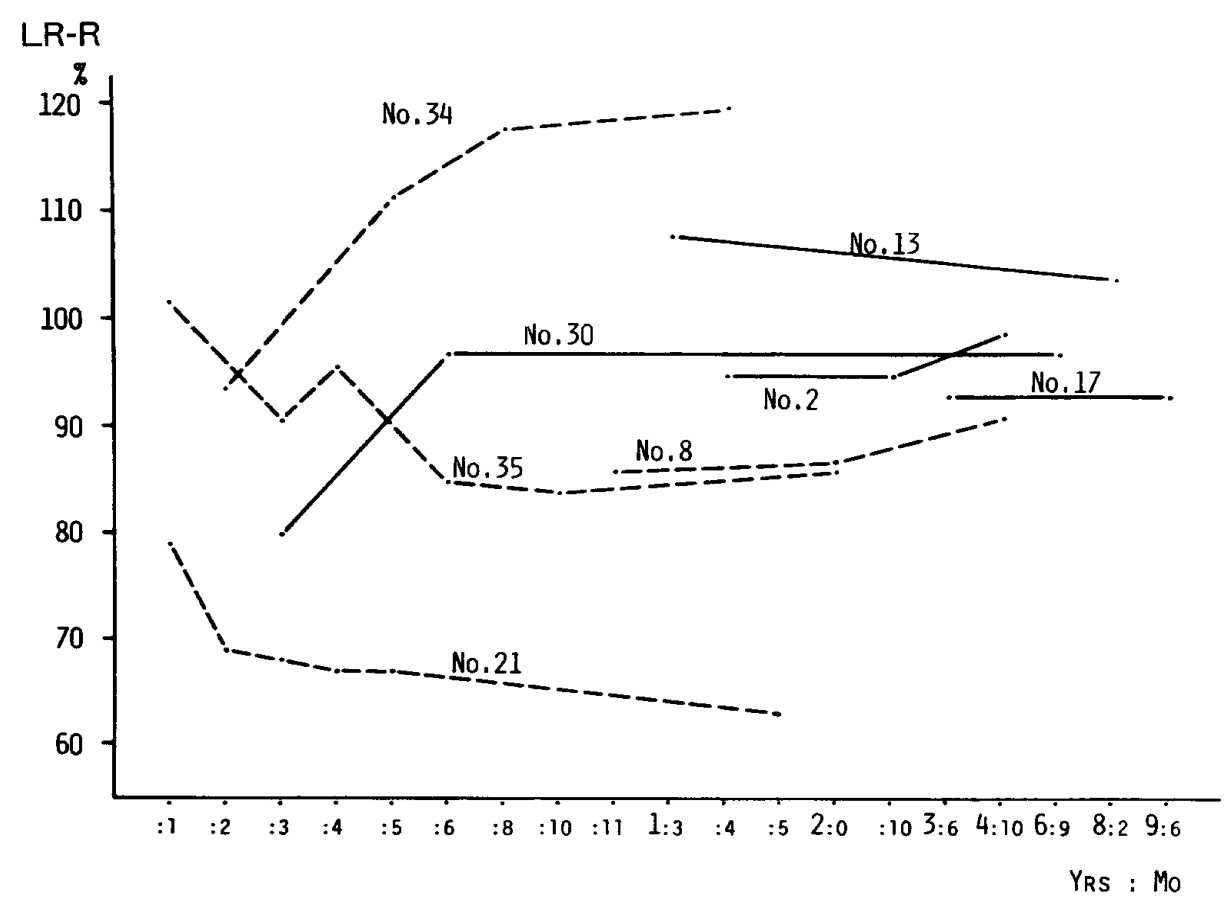

Fig 12 Changes with time of $\angle \mathrm{R}$-ratio Solid line: Transplanted group. Broken line: Replanted group. 

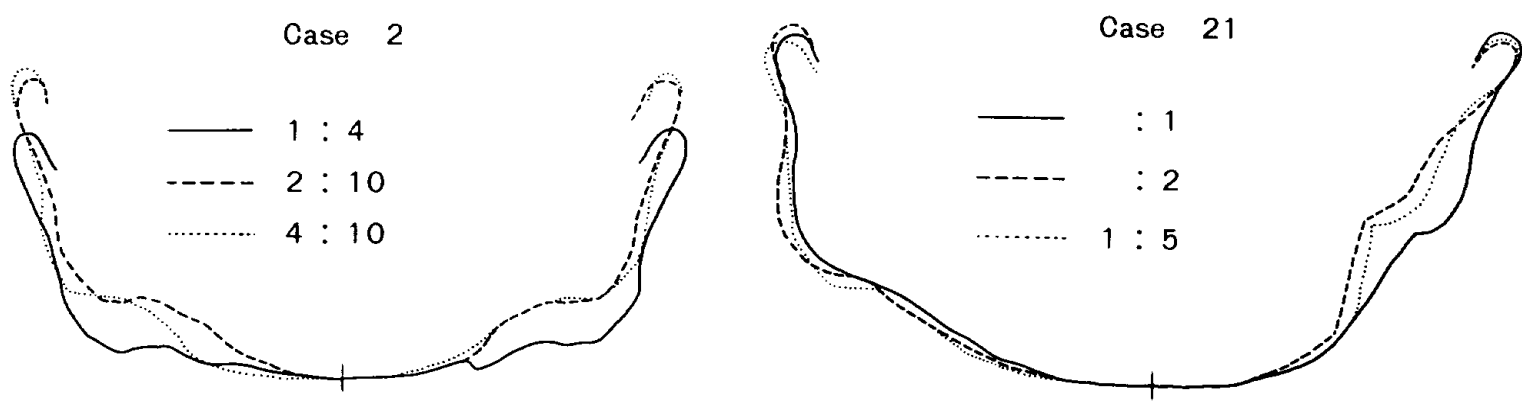

Case 8

Case 30
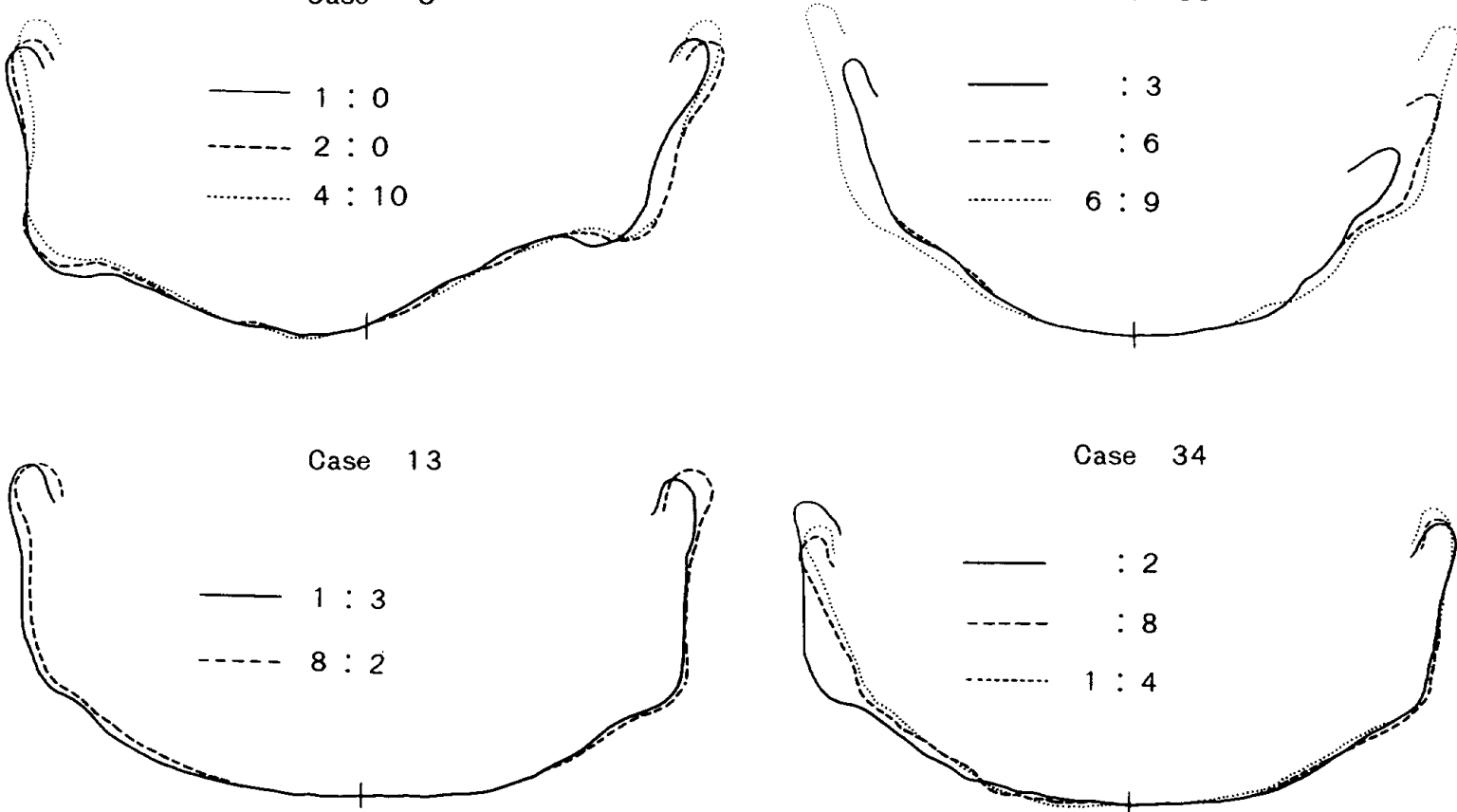

Case 34
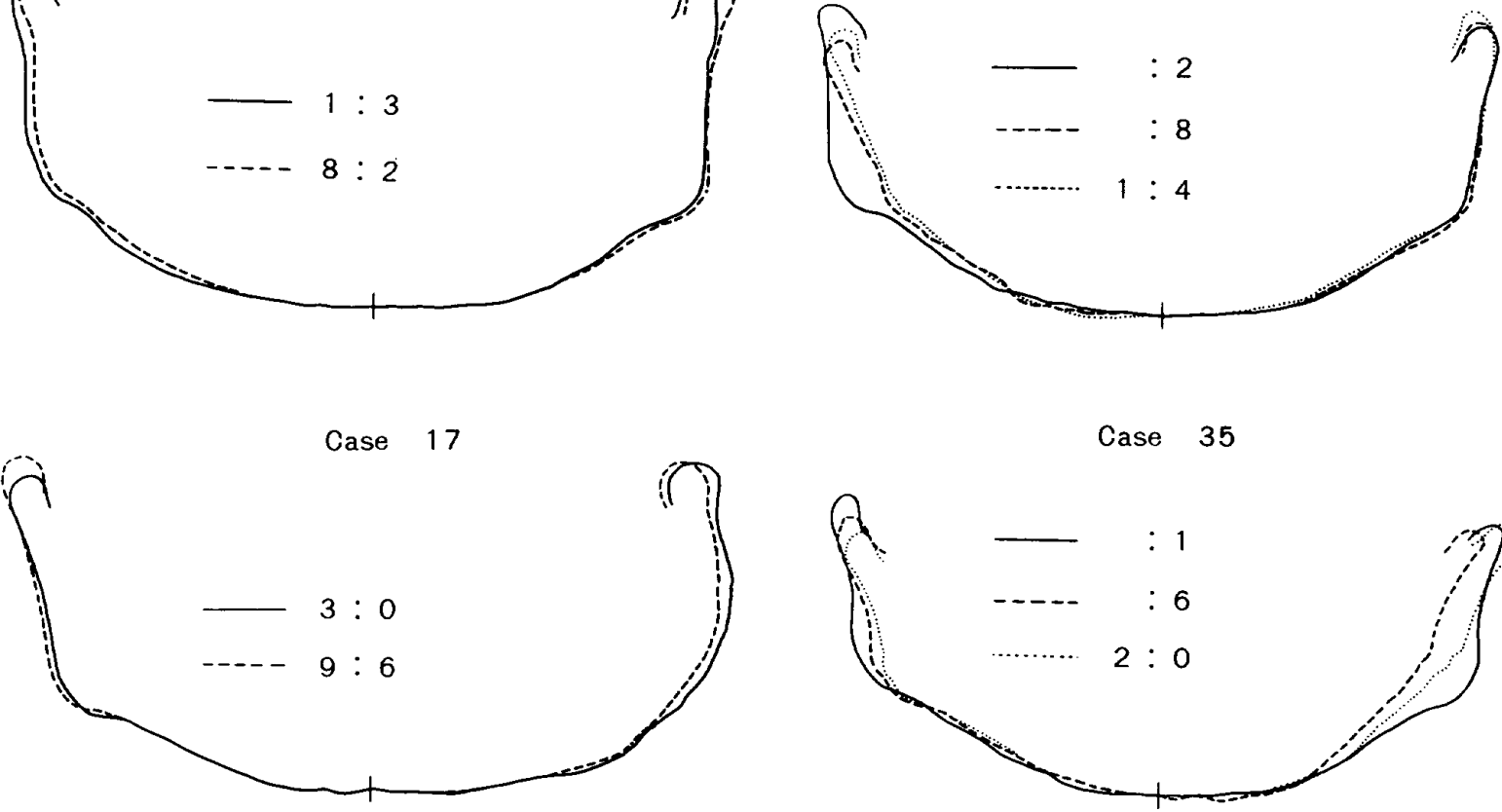

Case 35

Fig.13 Changes with time in form of mandibular arch. Figures following each line mean the period after operation (Year: Month)

目の像は類似している.

症例30 (左側IV型移植群) では術後 3 力月目に比較し て 6 力月目の像は手術側下類頭部の増大が示され，対称 性が回復している．6年 9 力月目の像では左右対称的な
下類骨の成長が示されている.

症例34（右側 IV 型再植群）では術後 2 力月目に比較し て 8 力月目の像は手術側下影角部から下影枝にかけての 惼平化が認められる.しかし， 1 年 4 力月の像とは類似 
している。

症例35（左側IV型再植群）も症例34 と同様の変化が， 術後 1 力月目と 6 力月目の像の間に見られるが，6力月 目と 2 年目の像の間の変化は殆んど認められない.

残る 4 例（症例 $2 ， 8 ， 13 ， 17$ ) においては, 全て術 後 1 年以上を経過した像の比較で, $\angle \mathrm{A}-\mathrm{R}$ の推移(図 12) と同様,下顎骨の輪郭に殆んど変化は認められない.

\section{C.X線像上特異な変化を示した症例}

対象35例中 6 例のX線像上に以下のような興味ある変 化を認めた。

\section{1. 症例 1}

23 才時にI 型肋骨移植を施行され, 術後 1 年 6 力月目 の像（図14一A）では骨切れ込みの透過性は明らかであ るが, 舌側中央部のオトガイ棘相当部に楔状の不透過像
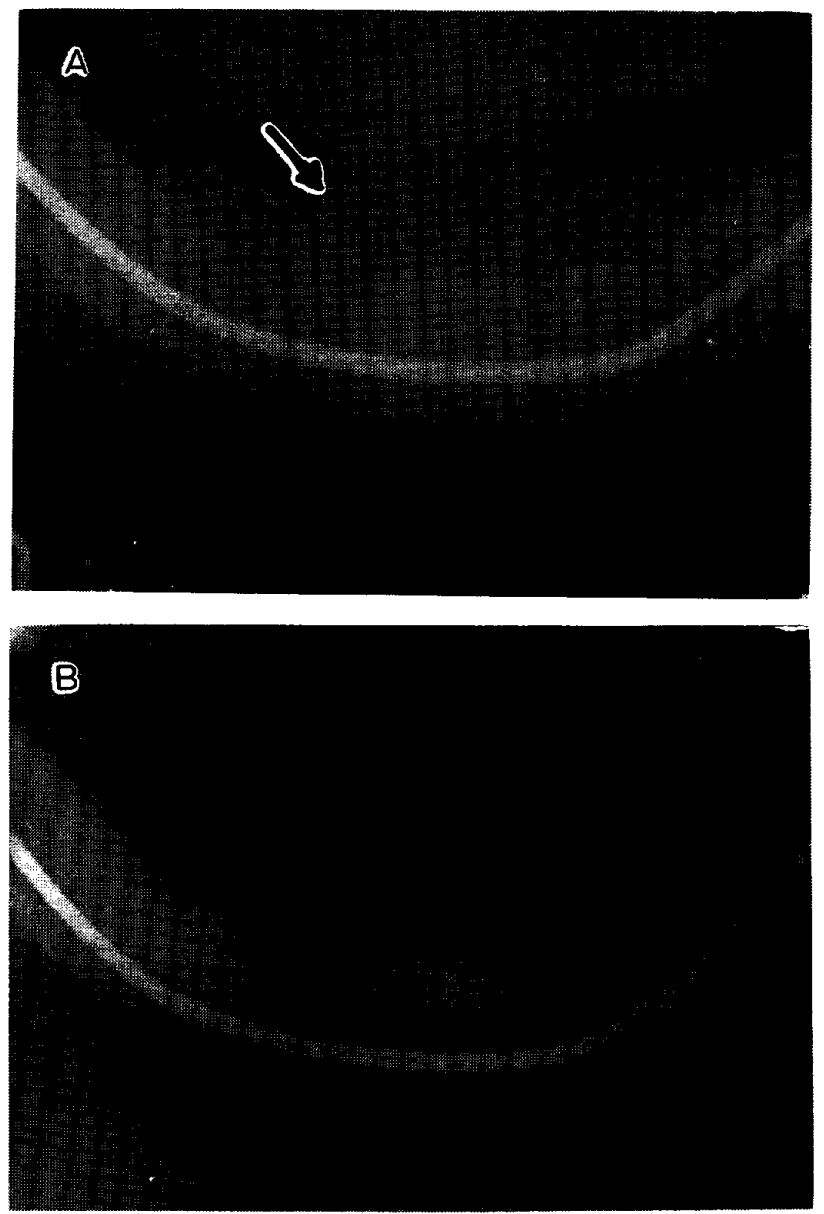

Fig.14 Occlusal film of Case No. 1.

A : One and half years after the operation of type $I$. Obscure radiopacity appears on the lingual mid-part of transplanted rib (arrow); B : Radiopacity is intensified in 3 years and 1 months post-operation.
を認める。術後 3 年 1 力月目の像（図14一B）では骨切 れ込み像は消失し，オトガイ欶相当部の不透過性も克進 している.

\section{2. 症例 14}

37才時に II 型皮質部再植を施行され，II型手術群中唯 一の形態不良例である，術直後の像（図15-A）では良 好な下頼弓の再建が示されているが，術後 3 力月目の類 間固定除去後より再植骨の吸収が始まり, 徐々に進展し て 5 力月目に病的骨折を来たした（図15一B）。しかし 一方, 術後 1 力月目より再植骨の上方に線状のX線不透 過像が出現し，徐々に明瞭となり，術後 1 年10力月目で は骨様不透過像を示している（図15-C）。

3. 症例 21

$42 才$ 時に III型皮質部再植を施行され，術後 1 力月目の 像（図16-A）では良好な下䫟马の再建が示されている が, 術後 2 力月目の顎間固定除去後より再植骨が転位し 下頇角部の変形を来した（図16-B）. 術後 1 年 5 力月 目では再植骨の吸収・菲薄化を認めるが，下頇弓の形態 は術後 2 力月目に比較して殆んど変化していない. 本症 例に拈いても, 術後 2 力月頃より再植骨の上方に線状の $\mathrm{X}$ 線不透過像が見られ，1年 5 力月目（図16-C）では より明瞭な像となっている。

4. 症例 22

44才時にIV 型腸骨移植を施行され，術後 9 年目の追跡 調查の際に移植骨中央より筋突起部にかけてX線不透過 像が見られ，13年 3 カ月目ではより明膫な像が認められ た(図17).

5. 症例 29

18才時にIV型腸骨移植を施行され，術後 1 年 6 力月目 に移植骨上方にX線不透過像が喼められ，2 年目にはさ らに幅広く明瞭な像になった（図18）。

\section{6. 症例 30}

9 才時にIV型腸骨（化骨未完成の腸骨）移植を施行さ れ，16才までの追跡調査において良好な形態修復を示し た症例である。術後 3 力月目では, 図19亿示されるよう に，遊離移植骨片が短く形態はかなり不良であるが（図 19-A)，術後 6 力月目では骨片上端の増生による下顎 頭様形態の回復が見られ，6年 9 力月目（図19-B）で は明らかな下頻頭・筋突起を含めた下顥枝の再生像が認 められた。

さらに, 移植骨の前上方部の䫟骨離断端部における骨 増生も著しいものが恐められた。

顔貌ならびに口腔所見においても図20に示すように， 何ら異常のない優れた再建状態が認められた. 

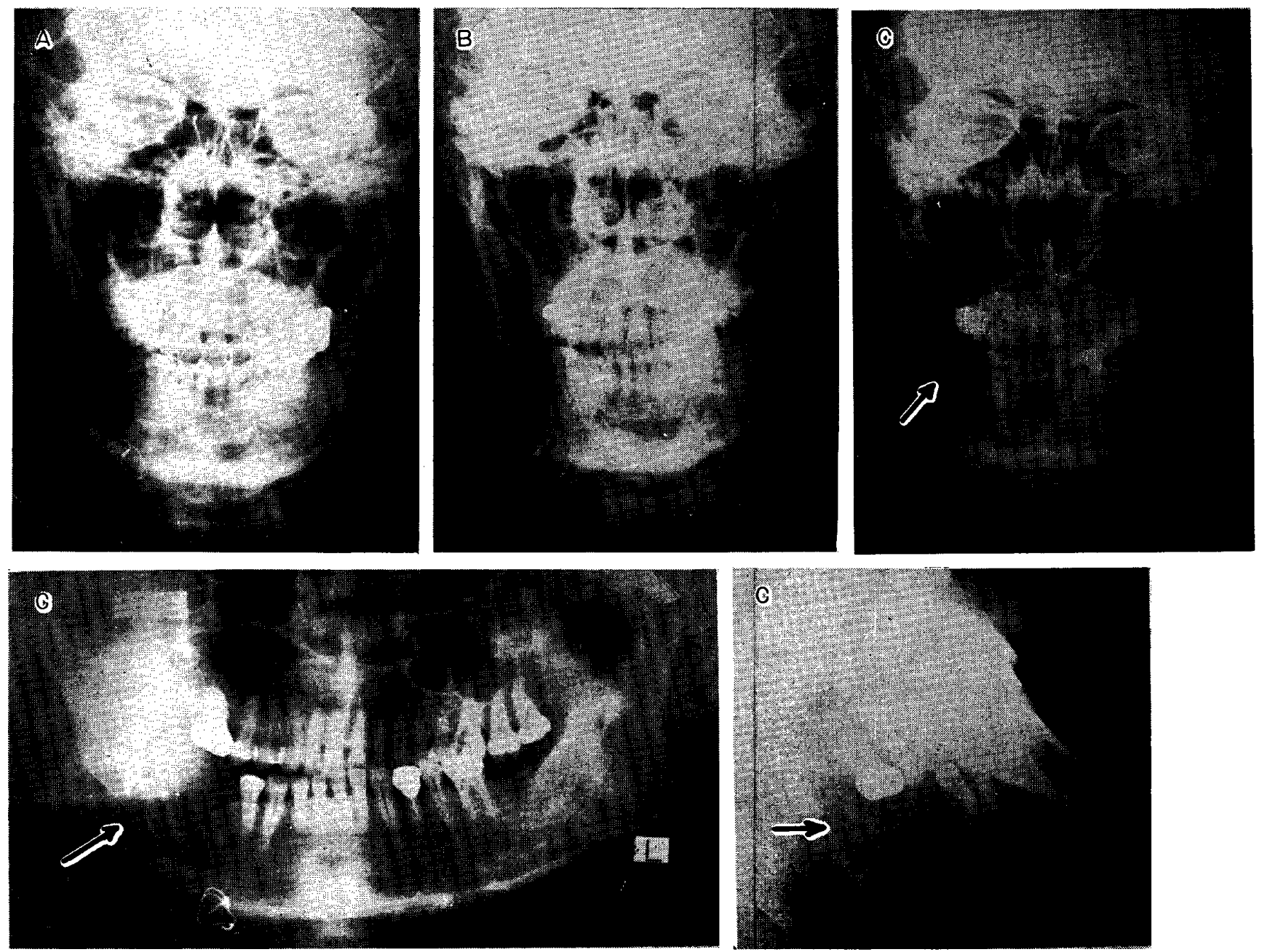

Fig.15 Roentogenograms of Case No. 14 .

A : Ten days after the operation of type II with cortex replantation;

B : Pathologic fracture caused by absorption of replanted cortex was found in the photo of 5 menths post-operation;

$\mathrm{C}:$ The photo of 1 year 10 months post-operation reveals the new growth of bone in superior area of replanted cortex (arrow).

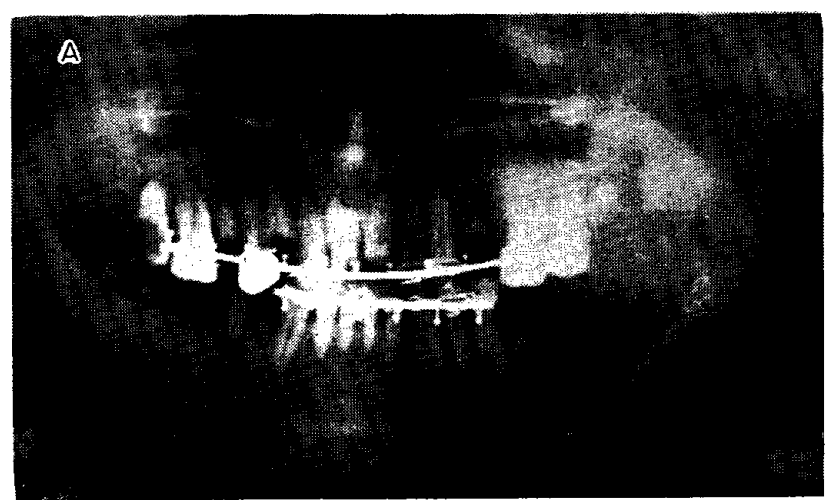

Fig.16 Orthopantomograms of Case No. 21. A : View, 1 month after the operation, of type III with cortex replantation;

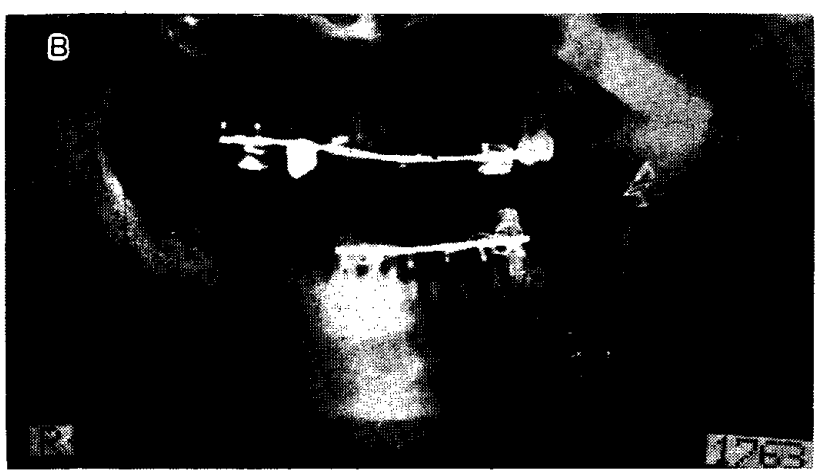

B : View, 2 months post-operation, shows the dislocation of the cortex; 


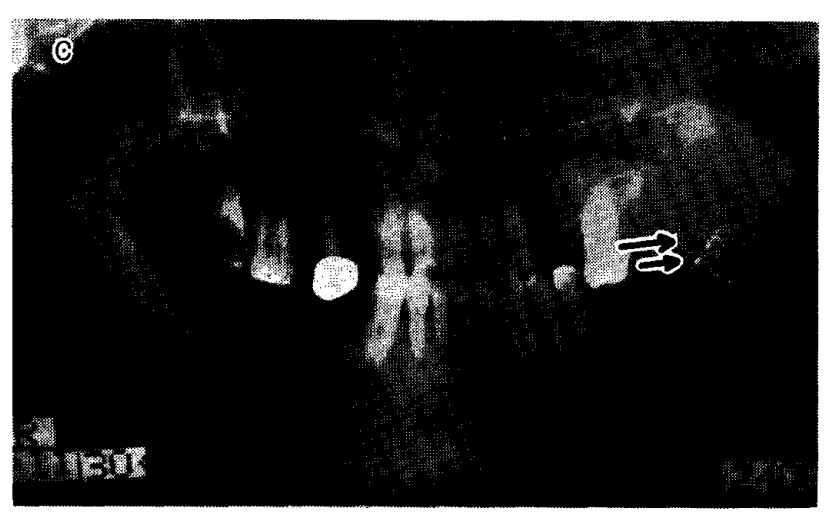

C: View, 1 year and 5 months postoperation, shows the new growth of bone (arrow).
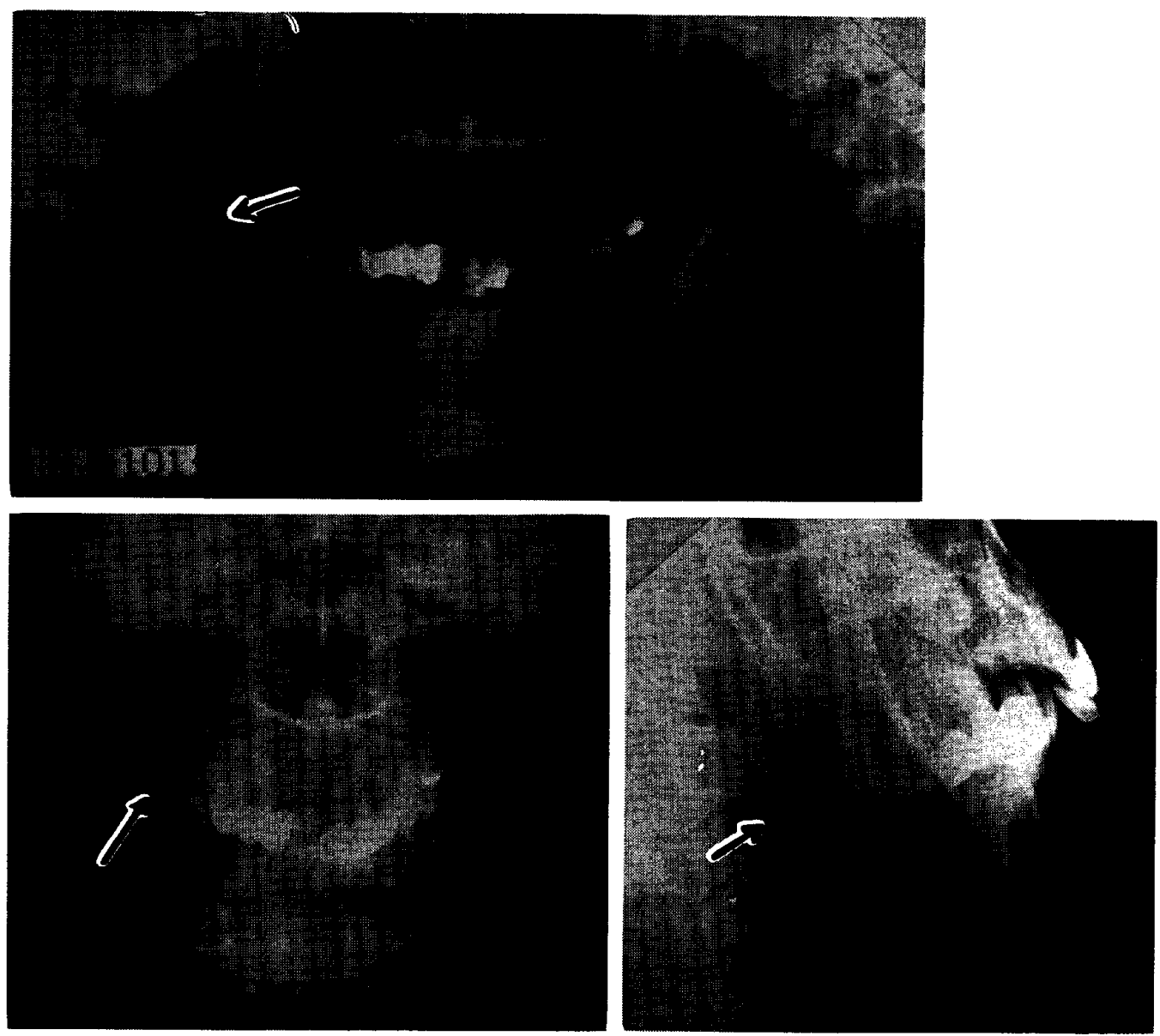

Fig.17 Roentogenograms, Case No.22. 13 years and 3 month after the operation of type IV of right condyle head to $\overline{5}$ area. Each arrow shows new growth of bone on the corresponding part of coronoid process.

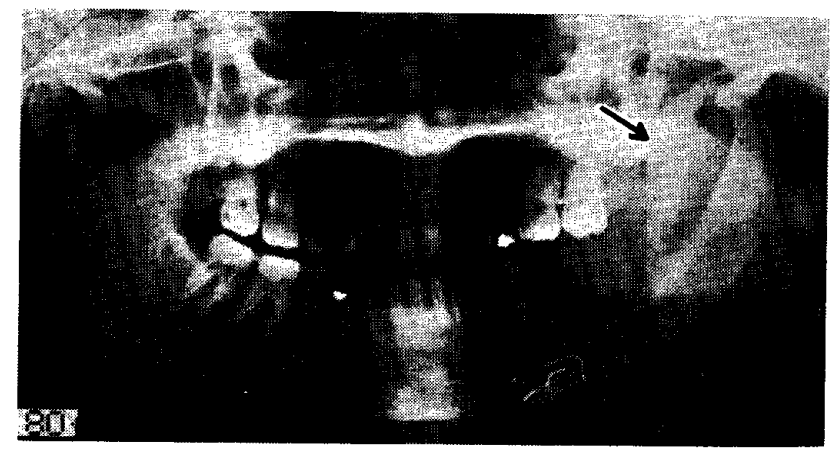

Fig.18 Orthopantomogram of Case No. 29. 2 years and 1 month after the operation of type IV with illiac transplantation. Clear radiopacity is shown on the corresponding part of coronoid process (arrow). 

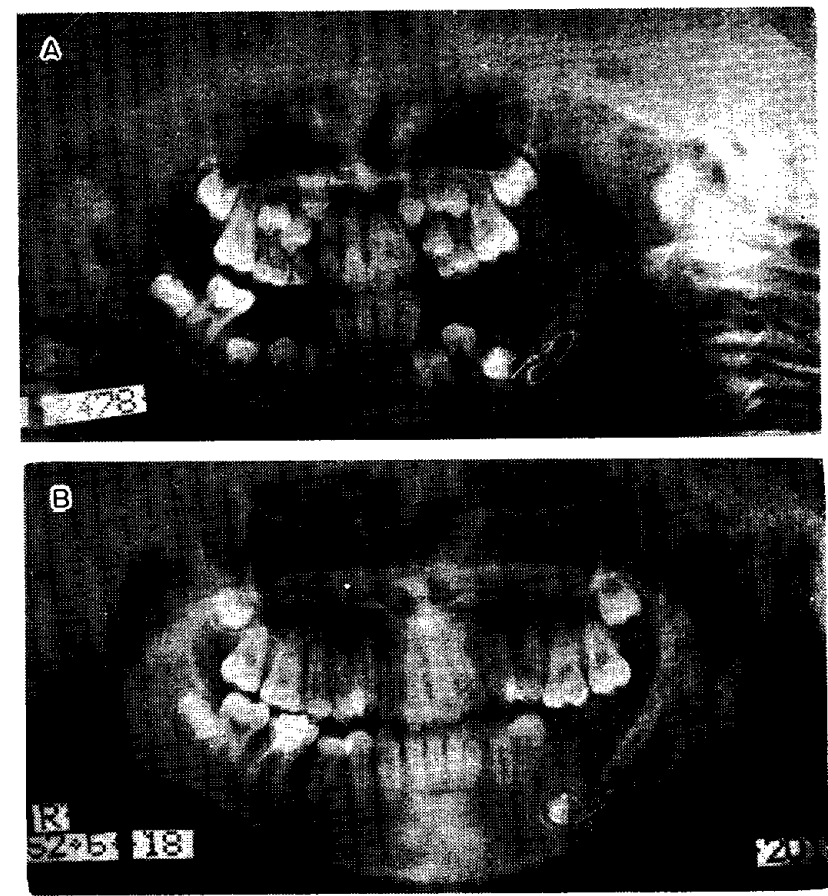

Fig.19 Orthopantomograms of Case No.30. A : 3 months after the operation of type IV with illiac transplantation;

B : Remarkable growth of bone making well developed form of left condyle and ramus is shown in the photo of 6 years and 9 month post-operation.

\section{総括ならびに考察}

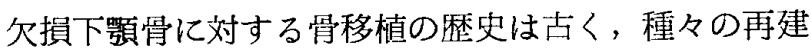
法が考案改良されてきた9!。しかしながら，再建の目的 である下頡の機能形態の回復を検討した研究は，本研究

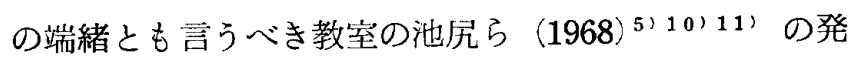
表以外には，Sailer $\left(1974{ }^{12)}\right.$ の文献を見るのみであ る.

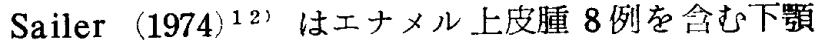
良性腫煌21例の部分切除・ 即時再建後の審美性, 関節運 動, 咬合咀嚼, 神経感覚, 筋運動, 移植骨状態と合併症 および追加処置について検討している. 但し，21例の手 術は全て口内法で施行されており，また全例の皮質部は 保存され部分切除に留まっている点が著者の研究対象と 異なる、移植骨片としては13例に自家腸骨，8例に自家 肋骨が適用されている. Sailer $(1974)^{12}{ }^{2}$ は顔貌形態の 審美性を評価するため, 次のような 4 段階の判定基準を
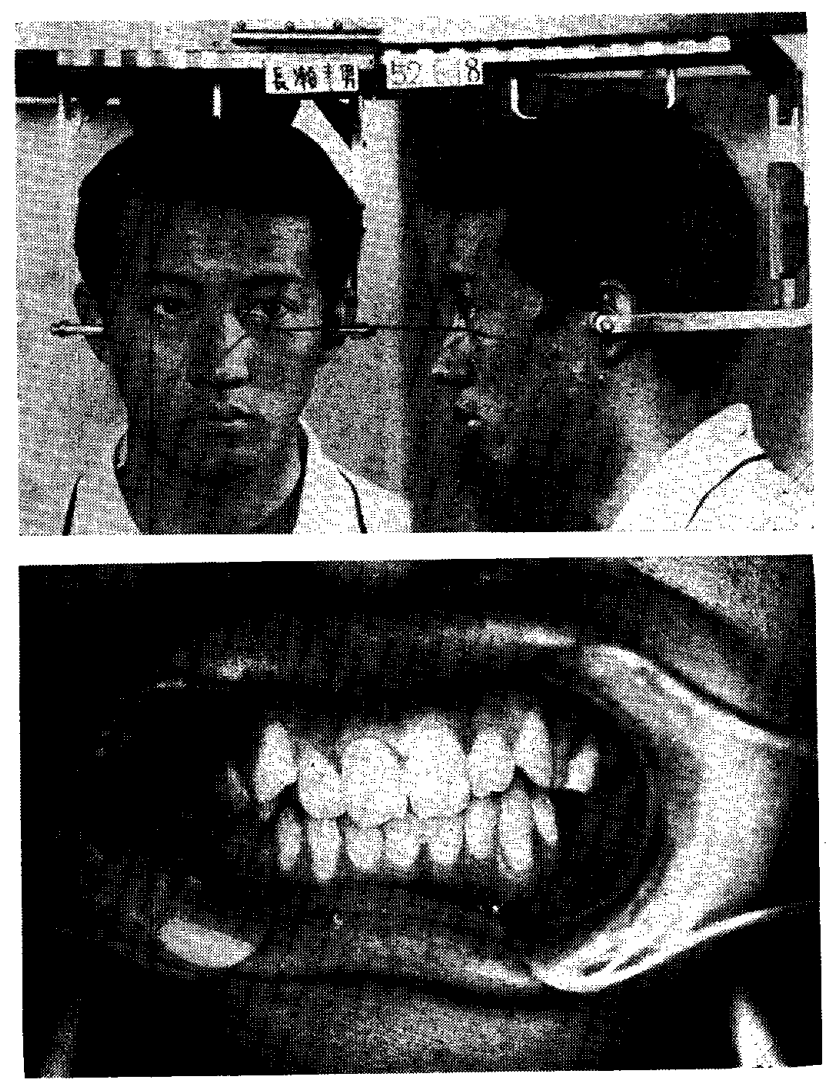

Fig.20 Facial and oral appearance of Case No. 30 .

His operation of type IV with illiac transplantation was performed on left side 6 years and 9 months ago, at the age of 9 .

用いている。

"Excellent": The specialist cannot differentiate between normal and operated sides during function.

"Good" : Slight difference in contour extraorally between the operated and normal sides which is neither apparent to the layman as an abnormality nor disturbing to the patient.

"Fair": The operated side can be differentiated from the normal side, but the difference is not great enough for further treatment from the patient's or surgeon's standpoint.

„Poor": Patient and surgeon desire further surgical correction because of asym- 
metry of contour.

すなわち，術者と患者の相互評価によって判定してい る. 著者も研究対象の35例全例に術後形態の自己評価を 行わせたが，客観性を高める意味から，術者側の評価の みにとどめた。

影顔面形態は個体差が著しいために，異常形態に対す る客観的ないしは定量的な評価判定は甚だ困難である。 雪科領域で応用の盛んな顔貌規格写真は正確な記録と計 測を行いうる方法であるが，正面視と側面視の 2 方向観 察しか行い得ず，下預弓形態を検討する本研究に適切な 方法ではない. また最近，顔面領域に応用の試みられて いるモアレ等高写真は形態計測上に種々の利点を有する が13)，下罰弓形態に関しては撮影規格上の問題が残り， その応用は未だ困難なようである。

従って, 著者は本研究に際して 3 人の検者の観察所見 を総合して, 認められる変形を全て記録し, 変形が全人 ない場合を形態良好と判定した。但し，手術創部の皮店 属痕については変形として取扱わず一切無視した．てれ は，皮膚切開には盤痕が必発し，その程度の評価は困難 であり,さらに本研究の課題の下頡弓形態に直接関与し ないためである・評価の対象は全て術後の形態に限定し たが，乙れは術前では腫場による顔貌の変形を伴う症例 が多く，また術前形態の正確な記録が困難であったた めに，術前術後の比較を行い得なかったてとによる。 Sailer $(1974)^{12}$ も術後の形態のみを評価の対象として いるのは，同様の理由によるものと思われる．

Sailer $(1974)^{12)}$ の検討の結果では, 対象21例中14例 (66.7\%) が Excellent, 7例 (33.3\%) が Good と 評価され，Fair または Poor とされた症例はない. 著 者の場合では，対象35例中20例 $(57.1 \%)$ が良好，15例 (42.9\%) が不良と判定されている. しかし Sailer

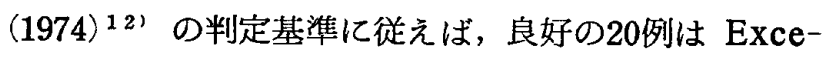
llent に，不良の15例中13例は Good に，残る 2 例（症 例22と23）は Fair に相当し，Poor に相当する症例は なかった. Sailer $(1974)^{12)}$ と著者の成績の差は，部分 切除と連続離断の手術法の違いに基くもので, 当然の結 果と言えょう。

さて，顎顔面形態の基本的様相は骨の状態によって大 きく左右される，そこで顥骨の形態を評価検討すること は, 顔面形態の検討資料を得る面加らも有意なものと思 われる. 生体の骨を観察する方法としてはX線が最も一 般的である，殊に額顔面領域においては，頭部X線規格 写真が有用で, 歯科矯正学をはじめ, 最近では口腔外科
領域における応用も試みられている ${ }^{14}$ ．

頭部X線規格写真は前面と側方の 2 方向上り観察され る.このうち, 側方規格写真は性別, 年令別の計測基準 值も決定されており，ルーチンな方法であるが，左右側 方を同時に同一平面に撮影するため, 左右の形態差を比 較することはできない，前面規格写真は下嚬骨ならびに 頭蓋顔面骨の前額平面の輪郭を観察するためには有用で あるが，弓状形態をなす下顎骨全貌の立体的観察，殊に 下顎角部の観察には適切でない。乙のため著者は，下頡 骨の弓状形態を展開させた像が得られるオルソパントモ グラムを用いて，下頡骨の形態を観察し検討した。

オルソパントモグラムは前額部, オトガイ部と左右耳 点の 4 点で固定して撮影されるために, 規格撮影像が得 られ易いと推察されるが, 未だ明らかにはされていな いそそてでまず，著者はオルソパントモグラムの規格性 に関して検討した．その結果，かなりの規格性を期待で きることが解った，すなわち，短期間に再撮影されたフ イルムを用いて「対称性試験」を実施した結果, 测定値

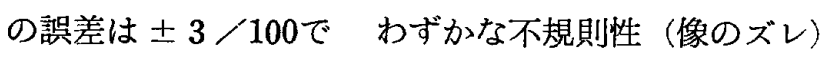
が認められたにすぎなかった。この結果はまた同時に， 対称性試験の測定值す $\pm 3 \%$ の誤差範囲で信頼性を有す るととを示していた。

オルソパントモグラムを数量表現するための対称性武 験は, 計測上の誤差を可及的小さくして再現性を有し, 且つ下顎骨外輪郭の対称性を簡易に検定して, 単純な表 現が出来るように努めた。 そのため, 前鼻棘および上顥 正中縫合を基準線とし, 各計測点もフィルム像または複 写図上で求め易い点のみとした。そ結果, 下頻骨の 外輪郭線は簡略化され, 計測が容易となり, 測定誤差も 低く抑えられだ.但し，オルソパントモグラムの像の特 性の一つに軌道軌跡の片寄りが指摘されており ${ }^{15)}$ ，被 写体実像とフィルム像との左右対称性は一致しないよう である.乙れは本研究の対照群の対称性試験の結果（表 5, 図 8）に明らかなように, 測定值のバラッキは土方 向に均等に展開していなかったことからも伺える。そこ で，著者は健側と手術側との比較は行わず，左側の計測 值を 100 に均一した右側換算值を用いて，対称性試験の 成績を検討した。

対称性試験の成績と肉眼判定成績とはかなり一致し て, 形態良好群では「正常範囲」内の数值を示す症例が 多いのに対し，形態不良群では著しい「正常範囲」外の 数值を示す症例が多かった．とのととは，下顎骨がその 顔貌形態の基本要因であるととを示すと同時に，逆に両 
者の成績が必ずしも一致しなかったてとから，影骨以外 の軟組織状態も顔貌形態の要因であることが示される. 変形の内容からも同様のことが伺える.すなわち, 肉眼 判定で形態不良とされた15例の変形内容の中で最も多い 変形は煩部の扁平化 (11例) で, 次いで下䫟编位 ( 8 例),

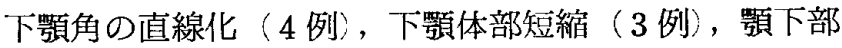
楩凹（2 例）の順であった。一方, 対称性試験では $\angle \mathrm{A}$ $-\mathrm{R}$ 次いで $\mathrm{AA}^{\prime}-\mathrm{R}$ と $\mathrm{C}^{\prime} \mathrm{A}^{\prime}-\mathrm{R}$ の項目において異 常值が多く見られ，下堮負角の異常，殊に角度の異常が多 いととが認められた。

煩部の扁平化は主にこの部の支持骨の実質欠損に基く もので，開口時の偏位は全てN型手術例に出現したてと から, 下顎頭部の位置や形態の異常, さらに軟組織の旅 痕化等に基く変形と考えられる。 また，下頻角部の直線 化は骨の吸収の結果であろう。

手術の型別では，肉眼判定および対称性試験の成績と もに，I型すなわちオトガイ部手術群が最も良く，特に 変形を示す症例はなかった．次いで，II型すなわち下類 体部手術群が良い成績を示した。

一般に, 直線状形態の下䫑体部に比較して, オトガイ 部は特異な彎曲を有するために骨移植再建は困難とされ

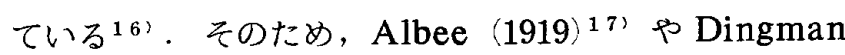
$(1950)^{18}$ ) のU型腸骨移植, Conley (1953) ${ }^{19}$ ) の Vit ${ }^{-}$ allium plate 併用法, Kazanjian ら (1959) ${ }^{20)}$ の 3 本骨移植, Millard 弓 (1967 $)^{7)} の$ Bent Rib Graft 等の多くの工夫がなされている，本研究においては，下 靦体部再建の II 型手術群よりも, オトガイ部再建の I 型 手術群の方がより良好な成績を示したことは興味深い。 その解秎としては次の理由が考元られる．第一に，I 型手術群に対してはオトガイ部額骨の彎曲を再現した Bent Rib または元の桴曲形態を維持した皮質部が適用 されたとと, 第二に， II 型手術は左右いずれか片側の䂓 骨を操作するために，非手術側との封称的な再建は術後 の変化も加わって困難であることが指摘される.換言す れば，オトガイ部の再建法として Bent Rib Graft お よび皮質部再植法が有用なととが示された。

Millard ら (1967) " の Bent Rib Graft に対して, 肋骨皮質は脆弱で彎曲付与のための縦溝形成により骨片 の完全骨折を来す恐机があり single piece of bone の 利点を損うとの反論があるが 16)，著者の研究封象にお いても教室の他手術例においても，そのような経験はな い.ただ, 不適切な綐溝形成のため縦溝間の皮質の一部 が剥離し部分的欠損を生じたことはあったが，術中術後
に何らの不都合もなかった。

下顎角部や下顎頭部まで切除する III型・IV型手術群で は形態良好例は少く，殊に移植群の成績は少っていた。 対称性試験においても正常範囲外の数値が多く見られ， 特に III型移植群の $\mathrm{C}^{\prime} \mathrm{A}^{\prime}-\mathrm{R}$, IV 型移植群 - 再植群の $\mathrm{C}^{\prime} \mathrm{A}^{\prime}-\mathrm{R}$ と $\angle \mathrm{A}-\mathrm{R}$ 亿著しい異常值が浔められた。 すなわち，III型移植群では下顎枝の長さの異常が，IV型 では移植群・再植群ともに下顎枝の長さと下顎角の角度 の異常が著しいことが示された。

III型・IV型手術群の成績が劣る理由としては, てれら の手術操作範囲が下影角を含み，さらに咬筋を始め主要 咀擸筋群の付着部位であるために， I 型や II 型手術群に 比較して容易に術後変形が惹起されやすいととが指摘で きよう、型・IV型とも移植群の方がやや劣る成績であ ったてとから， III型・IV型への再建法としては皮質部再 植法の方が若干有利かと思われる。しかしオルソパント モグラムの対称性試験の成績では, IV 型再植例にも下㖽 枝の長さと下頡角の角度の異常が示されており, 手術法 と適応の選択および術後の保定等に一段の工夫と配慮を 要するようである。

最近，下靧頭部を残存させて架橋腸骨移植を行う再建 法も試みられている211221231。

Weinstein 万 $(1963)^{21}$ は下琁骨中心性血管腫摘出 後の残存下顎頭と下䫁骨体部閒に腸骨移植を行った 1 例 を，長谷川ら $(1976)^{22)}$ は Titanium plate を併用し た架橋腸骨移植の 1 例を報告し，いずれも満足な成績を 得たと述へてている。工藤ら（1976） ${ }^{23)}$ はエナメル上皮 腫 4 例と Keratocyst 1 例の 5 例に下影頭を残存させ て架橋腸骨移植を行い，2 例に軽度の顔貌変形（下顎角 または煩部の陥凹）を来したのみで良好な形態の回復を 得たと報告している. 本法は機能形態回復の面からは皮 質部再植法の利点を，䏦煌拡大切除の面からは自家骨移 植法の利点を取入れており，症例を選択すれば有用な手 術法と思われる。

さて，再建後の㖽骨の形態変化の特徽を検討した結果 は図10に示したとおりで，例外的症例を除けば，右側手 術群では「く」形を, 左側手術群では逆「く」形を示し, 手術側の短縮化と下影角の扁平化が認められた. 右側手 術群においてより明らかな図形が示されたのは，オルソ パントモグラムの像の歪み ${ }^{132}$ に上るものと思われる。 皮質部再植群においてもてのような変形がみられた理由 としては，颚骨離断操作に伴う骨実質の損失，術後の血 行障害と盤痕による短縮化，それに伴う菲薄な皮質骨片 
の変形が考えられる.

骨移植による顕骨再建法の成績向上のために種々の工 夫がなされているととは前にも触れたが，変形予防の工 夫として金属板による補強法が発表されてかなり優れた 成績を紹介しており 22'，今後の発展に期待が持たれる.

再建後の額変形の時期的推移について検討した結果は 図12・13に示したすすなわち，症例によって時期や程度 の差はあるが, 術後 8 カ月までは再建部顎骨の形態はか なり変化する場合があるのに対し，術後 1 年以降の変化 は殆んど認められなかった，従って，てのような再建後 の形態を検討する場合には，術後少くとも 1 年を経過し た症例を対象とすべきであろう. 本研究の対象は全て 1 年以上経過した症例であった。

石井 万 $(1977)^{24)}$ は骨シンチとX線像を用いて下影 骨移植例を観察した結果, 術後 3 力月目に移植骨部への R I 集積は peak 亿達し，X線像上では部分的半透過性 を認めるが骨性癒合は完了していず, 術後 1 年半頃まで mild な造骨機能の維持が示唆されたと述へてている。こ れらの所見に基いて，骨移植後の固定期間は最低 3 力月 を必要とし, また保定期間は術後 1 年半を要すると主張 している. Sailer $(1974)^{12)}$ も骨瘾合の完了には術後 6-9 力月を要すると述へ，さらに彼の研究対象21例中 3 例に偽関節を生じた理由として術後の不適切な固定を 指摘している，著者の対象症例においても，病的骨折を 来した症例14および再植骨片の転位を来した症例21の変 形は術後 3 力月目または 2 力月目の濒間固定除去直後に 生じているとと, さらに前述したように，術後 8 力月ま では再建部の形態は不安定である事実から，術後の適切 な固定とそれに続く比較的長期間の保定は再建後の成績 向上のために不可欠と考える.

顎切除後の骨欠損部に新生骨が認められた臨床例はし ばしば報告されているが12２5２6２7，本研究において も6例に骨新生像が確認された。

このうちの 4 例では, 移植骨片または再植骨片より離 れた上位に骨新生像を示すX線不透過像が喼められた. てれは従来からの見解である残存骨膜に由来する骨新生 251261281291 と解粕できるようである. 他の 2 例のう ち，オトガイ部肋骨移植の 1 例にはオトガイ棘の再生を 示すX線不透過像が，IV 型腸骨移植の 1 例には下頻頭・ 筋突起を含む下頻枝のほぼ完壁な再生像が認められた。 オトガイ棘や下頻頭・筋突起の再生は, Obwegeser $(1971)^{27)}$ が述へているように，再建部が十分満足な 機能を営んだ結果あるいは営んでいる証拠としての形態
修復と言えよう。下影頭の再生は既に数例が報告されて (いが25２6２7)，筋突起およびオトガイ棘の再生例は， 教室の池尻らが症例 1 のオトガイ䊂再生を発表した ${ }^{61}$ 10)11)以外には，他仁報告を見ないようである. Bent Rib Graft は Millard ら (1967) ${ }^{n}$ が考案発表した再 建法であるが，彼の手術対象は悪性腫場患者で顎骨周囲 の軟組織をも広範に切除するためか, オトガイ䊂の再生 例は未だ報告されていない，すなわち，オトガイ棘の再 生のためにも移植部周囲の骨膜の残存が大きな要因であ り，筋突起の再生についても同様と考元る.

骨新生のための他の要因として年令が指摘されている

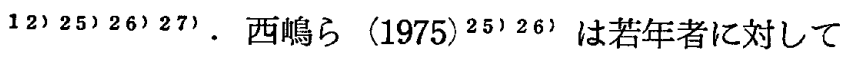
骨新生を期待し，骨膜残存手術法（骨膜下影骨離断 ${ }^{26}$ ) を積極的に試みている．西嶋ら (1975) 25) 26) の文献考 察によれば, 他家報告の骨新生例は大半が10代以下の若 年者であったと述へている，著者の研究対象において も，対象中最年小の 9 才例（症例 $30 ）$ が最も顕著な骨再 生像を示したことは繰返し述べた。しかし一方, オトガ イ䊂の再生像を示した症例の手術時年令は 23 才で, 他の 4 症例を，18才例を別とすれば，37才，42才，44才時に 手術された症例で，比較的高年者に対しても骨新生能力 を期待できる．乙の期待を成功させるためには，DeChamplain (1973) ${ }^{28)}$ が言及しているように，骨芽細 胞の母床となる骨周囲軟組織とりわけ骨膜の保存的剝離 が第 1 の要因であろう.

6 例の骨新生を示すX線不透過像の確弪照時期は術後 1 力月目から 9 年に亘っていた。 但し，乙れら症例に対す る追跡調查は定期的に行われたものでなかったため, 央 際には，より早い時期に骨新生が開始していたと推察さ れる. 西嶋ら $(1975)^{25)}$ 26) の4例におけるX線不透過 像の出現は術後 2 週から 1 力月以内で，他家の報告例に おいてもせいぜい 6 力月以内であったと述へている.

さて, 再建手術後の機能の回復は形態修復以上に重要 な問題である.今回,形態の修復を研究課題としたため， 機能面に関しては触れなかった．対象35例全例の機能上 の変化についても検討し，特筆すべき障害は 1 例もない ことを確認したが，その詳細は今後の機会に譲りたい．

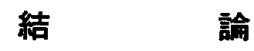

9 才から 76 才までの下頡骨エナメル上皮腫患者 35 例を

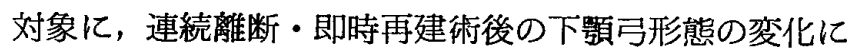
関して検討した結果，次のような知見を得た。

1. 即時再建後 1 年以上経過した時点での判定の結果, 
対象35例中 20 例 $(57.1 \%)$ は何ら変形のない良好な顔貌 形態で，残る15例 $(42.9 \%$ ）は閉口または開口時の変形 が認められた．その変形の内容としては，煩部の徧平化 が最も多く, 次いで開口時の下顎偏位，下颚角の直線化， 下颚体部短縮, および顎下部俢凹の順であった。但し， これらの変形の程度は軽く，醜形と表現するに至らなか った。

2. 手術部位別では，オトガイ部再建群は全例が形態良 好で，オトガイ部再建法として適用した皮質部再植法お よび Bent Rib Graft の有用性が示された. 次いで, 下影体部再建群が優れた成績で, 殊に腸骨移植再建群は 全例が形態良好であった，從って，下額体部は腸骨移植 再建法の適応部位と言える.

下㖽体一下顎角部および下顎角一下靧枝部の再建群で は殆んどの症例に変形が認められ，前者には煩部の扁平

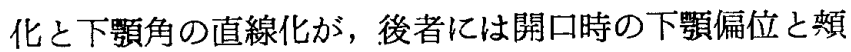
部の扁平化が特徽的であった。乙れら下疑後方部に対す る再建法としては，腸骨移植法よりも皮質部再植法の方 がやや有利なととが示唆された。

3. オルソパントモグラムは像の片寄りを有するが，か なりの規格性を期待でき, 下頻骨形態の検索法として有 用と思われた。乙の像の分析の結果は肉眼判定成績とか なり良く一致していた。また，分析パターンの検討によ

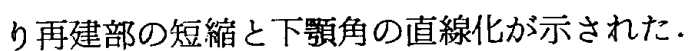

4. 再建後の下顕形態の変化を追跡した結果, 術後 8 力 月以内は変形を来たす症例があるに対し， 1 年以降の変 化は殆んど認められなかった。

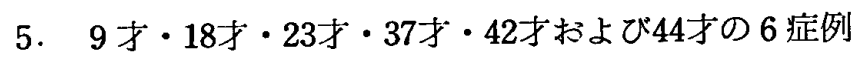
亿骨新生像が示され，9才例には下顕頭および筋突起を 含むほほ完壁な下顎枝の再生像が，23才例ではオトガイ 棘の再生像が認められた。

6. 以上の知見より, 下暺骨即時再建術は良好な形態修 復を十分に期待できる方法であることが判明した。た だ，成績向上のためにはさらに種々の配慮を要し，特に 術後 1 年間は適切な固定と保定が必要と思われた。

(稿を終るに臨み，本研究を命じられ終始御想篤なる 御指導御鞭墶を賜わりました恩師池尻茂学長に満腔の感 謝を捧げます．また，種々の御指導御教示を賜わりまし た梶山稔教授, 山田長敬教授, 福岡幾科大学古本克磨教 授をはじめ, 研究上多大の御援助を賜わった教室の皆様 に，心からの感謝を捧げます.）
文献

1. Stout, R. A., Lynch, J. B., et. al: The conservative surgical approach to ameloblastomas of the mandible, plast. Reconstr. Surg. 31:554-562, 1963

2. Mehlish, D. R., Dahlin, D. C., et. al: Ameloblastoma; a clinicopathologic report, J. Oral Surg. 30:9-22, 1972

3. Shatkin, S. and Hof fmeister, F. S. : Ameloblastoma ; a rational approach to therapy, Oral Surg. $20: 421-435,1965$

4. 大曲靖夫・池尻 茂：口腔疾患の検查と㟝断（第 3 版), 医霜薬出版, 東京, 1976,161

5. 池尻 茂・安藤龍男: 骨皮質部再植によるエナメル 上皮腫の下顎骨形成について, 日口外誌 14 ： 54-59, 1968

6. Lucas, R.B. : Pathology of tumors of the ora1 tissues (2 nd Ed.), Churchil Livingstone, Edinburgh and London, 1972, 30

7. Millard, D. R., Meisels, D. O., et.al : Immediate repair of radical resection of the anterior arch of the lower jaw, Plast. Reconstr. Surg. 39:153-161,1967

8. Yang, C. C. : A study on the mandible fractures, 九州宷会誌 $22 ： 310-319,1969$

9. Scheuermann, H. A. : Osteoplasty and its application in oral surgery, Oral Surg. $20: 436-443,1965$

10. 池尻 茂・古本克磨・他：エナメル上皮腫におかさ れた下頡弓の再建 (会), 日日科誌 $20: 267$ ， 1971

11. 池尻 茂・古本克磨・他：エナメル上皮腫に侵され た下顎弓の再建 (会), 形成外科 $15: 16-17$, 1972

12. Sailer, H. F. : Experiences with intra-oral partial resection and simultaneous reconstruction of the mandible in preoperatively non-infected cases, J. Max.-Fac. Surg. $2: 173-178,1974$

13. 河合 幹・山本 忠・他：顔面形龍の立体的計測法 亿関する考察，日口外誌 $20 ： 599-604,1974$ 14. 西嶋克己・森田知生 - 他: 頼口腔外科領域における 頭部X線規格写真の臨床的応用, 日口外誌 15 
: 139-156, 1969

15. 久保田三平・尾沢光久・他：オルソパントモグラム に関する研究 ; 軌道軌跡の再検討 (会)，曾科 放射線 $13: 112,1973$

16. Seward, G. R. : A method of replacing the anterior part of the mandible by a bone graft, Brit. J. Oral Surg. 5:99-105, 1967

17. Albee, F. H. : Orthopedic and reconstruction surgery, Saunders, Philadelphia, 1062 ; cit. by 16 (Seward's paper)

18. Dingman, R. O.: The use of iliac bone in the repair of facial and cranial defects, Plast. Reconstr. Surg. 6 : 179-195, 1950

19. Conley, J. J. : A technique of immediate bone grafting in the treatment of benign and malignant tumors of the mandible and a review of seventeen consecutive cases, Cancer $6: 568-577,1953$

20. Kazanjian, V. H. and Converse, J. M. : The surgical treatment of facial injuries (2 nd Ed.), William \& Wilkins, Baltimore, 1959, 896

21. Weinstein, I., Yamanaka, H., et. al : Resection and reconstruction of mandible for central hemangioma, Oral Surg. 16

$$
: 2-7,1963
$$

22. 長谷川明 - 土田有宏・他: Titanium plate 補強に よる下筫骨即時再建術について, 日口外誌 22 :25-29, 1976

23. 工藤啓吾・大屋高徳・他：下䫑部骨移植の臨床的研 究, 日口外誌 $22: 816-820,1976$

24. 石井保雄 - 兵行 忠・他：下額骨々移植後における 骨シンチとX線像との臨床的検討, 日口外誌 $23: 29-40,1977$

25. 西嶋克己・岸 幹二・他：下頻頭を含めた下類骨片 側離断術後の骨新生について, 日口外誌 21 ： 491-497, 1975

26. 西嶋克己・岸 幹二: 骨膜下額骨離断後の骨新生, 歯界展望 $46: 251-258,1975$

27. Obwegeser, H. L. : Deformities of the jaw ; Plastic surgery in infancy and childhood (Ed. by J. C. Mustarde), E \& S Livingstone, Edinburgh and London, 1971, 90 $-91$

28. DeChamplain, R. W. : Mandibular reconstruction, J. Oral Surg. 31:448-462, 1973

29. Richter, H. E., Boyne, P. J., et. al : New concepts in facial bone healing and grafting procedures, J. Oral Surg. 27 : 557-559, 1969 